\title{
Kamusal Mekân Kalitesini Yükseltmek İçin Kentsel Tasarım Araçlarından Nasıl Faydalanabiliriz? ${ }^{1}$
}

\author{
S. Nur Yener Metin² \\ ORCID: 0000-0002-1021-899X
}

\author{
Sibel Polat ${ }^{3}$ \\ ORCID: 0000-0003-4380-0457
}

\section{Öz}

Kamusal mekânlar geçmişten beri toplumsal yaşamın gelişmesinde ve sürdürülmesinde önemli roller üstlenmektedir. Sosyalleşme ve ticaret olanaklar sunmaktan, kent kültürünü ve kimliğini korumaya, toplumun fiziksel ve ruhsal să̆lığın geliştirmekten, hizmetlere ve bilgiye erişmeye kadar pek çok gereksinim kamusal mekânlar tarafindan sağlanır. Bu durum kamusal mekânların fiziksel, sosyal ve ekonomik boyutlarıla birlikte yönetimini gerektirir. Bütüncül bir bakış açısıyla yönetilmeyen kamusal mekânlar bakımsızlık, kalitesizlik, terkedilme, güvensizlik, özelleşme gibi pek çok sorunla karşı karşıya kalabilir. Bu sorunların önüne geçebilmek için bugün pek çok gelişmiş ülkede kamusal mekânları tasarlamaya ve geliştirmeye yönelik kentsel tasarım araçları kullanılmaktadır. Ülkemizde ise kentsel tasarım araçları geliştirme konusundaki deneyimler henüz yetersiz olduğundan, bu çalışmada kamusal mekân kalitesinin arttırılmasında kentsel tasarım araçlarının rolünü araştırmak amaçlanmıştır. Çalışmada öncelikle literatür araştırması yapılarak kamusal mekân kalitesini oluşturan boyutlar, kriterler ve bileşenler tanımlanmıştır. Daha sonra yedi farklı kentten seçilmiş kentsel tasarım araçlarındaözellikle tasarım rehberlerinde- kamusal mekânlarda kaliteyle ilgili hangi bileşenlerin ve tasarım ilkelerinin öne çıktı̆̆ı tespit edilmiştir. Sonuç olarak, Türkiye'de kamusal mekânların kalitesini arttırmak için geliştirilecek bir tasarım rehberinde yer alması önerilen kalite kriterleri ve bileşenleri tanımlanmış, bunların uygulanma alanlarına göre tasarım ilkeleri oluşturulmuştur. Yapılan çalışmanın Türkiye'deki kamusal mekânların geliştirilmesine yönelik tasarım rehberlerinin hazırlanmasında merkezi ve yerel yönetimlere yol göstereceği düşünülmektedir.

Anahtar Kelimeler: Kamusal mekân, kamusal mekân kalitesi, kentsel tasarmm araçlan, tasarım rehberleri

\footnotetext{
${ }^{1}$ Bu makale Doç. Dr. Sibel Polat'ın danışmanlığında S. Nur Yener Metin'in yazdığı Bursa Uludağ Üniversitesi Fen Bilimleri Enstitüsü Mimarlık Ana Bilim Dalı'nda tamamlanan “Kamusal mekân kalitesinin sağlanmasında kentsel tasarım araçlarının rolü" adlı yüksek lisans tezi çalışmasından üretilmiştir.

2 Y. Mimar, E-mail: nuryenerr@gmail.com

${ }^{3}$ Doç. Dr., Bursa Uludağ Üniversitesi, E-mail: sibelpolat@uludag.edu.tr
}

idealkent @ Kent Araştırmaları Dergisi (Journal of Urban Studies)

http://idealkentdergisi.com

Geliş Tarihi Received Date: 14.02.2021 Kabul Tarihi Accepted Date: 07.09.2021 


\title{
How Can We Benefit from Urban Design Tools to Increase Public Space Quality?
}

\author{
S. Nur Yener Metin ${ }^{4}$ \\ ORCID: 0000-0002-1021-899X
}

\author{
Sibel Polat ${ }^{5}$ \\ ORCID: 0000-0003-4380-0457
}

\begin{abstract}
Public spaces play important roles in developing and maintaining social life. Many benefits are offered by public spaces, from providing socialization and trade opportunities, protecting urban culture and identity, improving physical and mental health of the community, accessing services and information. Public spaces, which are not managed from a holistic point of view, may face many problems such as neglection, poor quality, abandonment, insecurity and privatization. To prevent these problems, various design tools are used in many countries to develop and design public spaces. As the practice of developing urban design tools is not enough in Turkey, this study aimed to investigate the role of urban design tools in increasing the quality of public spaces. In the study, public space quality dimensions, criteria and components were identified by making a literature research and seven urban design tools, especially design guidelines used in different cities were examined. As a result, public space design principles for the different elements of public space were identified to increase public space quality in Turkey. It is expected that central and local governments can benefit from this study in the preparation of design guidelines about public places in Turkey.
\end{abstract}

Keywords: Public space, public space quality, urban design tools, design guidelines.

\footnotetext{
${ }^{4}$ Master of Architecture, E-mail: nuryenerr@gmail.com

${ }^{5}$ Assoc. Prof., Bursa Uludağ University, E-mail: sibelpolat@uludag.edu.tr

idealkent @ Kent Araştırmaları Dergisi (Journal of Urban Studies) 


\section{Giriş}

Kamusal mekânlar insanların gündelik ihtiyaçlarını karşıladığı ve kültürel etkinliklerini gerçekleştirdiği, bireyleri birbirine bağlayan ortak mekânlar olarak tanımlanmaktadır (Kostoff, 1999). Sokakları, meydanları, parkları içeren ve binaları saran tüm boşlukları kapsayan kamusal mekânların kente en önemli katkısı birçok insanı buluşturarak sosyalleşme fırsatları ve etkileşim alanları oluşturmasıdır (Gehl, 2001; Madanipour, 1996). Ancak son yıllarda kamusal mekânlar bakımsızlık, kalitesizlik, terkedilme, güvensizlik, özelleşme gibi problemlerle gündeme gelmektedir. Sennett (2002)'ye göre, bu problemlerin temelinde 19. yüzyıldan itibaren sanayi kapitalizminin ve sekülerleşmenin etkisiyle hayatın her alanında yaşanan hızlı değişimler nedeniyle kamusal yaşamın çözülmesi yatmaktadır. İnanç bunalımı, içe dönme, duygularını saklama, mahremiyetin önem kazanması, dış dünyaya karşı yerel bir savunma mantığı ve toplulukların yükselişi insanların kamusal mekânlardan çekilmesine neden olmuştur. 20. yüzyıldan itibaren ulaşım/ iletişim teknolojilerinin gelişmesi ve küresel ekonomik düzenin toplumsal yapı ve kentsel mekân üzerindeki hakimiyetiyle birlikte kamusal yaşamın parçalanması devam etmiştir. Günümüzde sosyal medya platformları sanal bir araya gelme ortamları yaratarak, dışa kapalı konut alanlarının yükselişi de toplumsal ayrışmayı körükleyerek kamusal mekânların terkedilme sürecini hızlandırmaktadır. Bununla birlikte geçtiğimiz yıl yaşanan Covid 19 pandemisinin yarattı̆̆ yeni yaşam koşulları insanları zorunlu olarak evlere hapsederken, yeni normale uygun, kaliteli kamusal mekânlara olan gereksinimi gündeme getirmiştir.

Kaliteli kamusal mekânların geliştirilmesinde yönetim önemli bir konu olarak karşımıza çıkmaktadır. Carmona (2010a, 2010b)'ye göre yönetilmeyen kamusal mekânlar bakımsızlık, sahipsizlik, güvensizlik, trafik baskısı, mekânsal kalitenin düşüklüğü, erişim ve etkinlik yetersizliği, sosyal yapıda değişim ve parçalanma ve ayrıca içe dönük yaşam etkisiyle yarı özel ve sanal mekânların tercih edilmesi sonucu kullanılmama gibi problemlere neden olurken, aşırı yönetilen kamusal mekânlar ise güvenlik veya bakım maliyetinin yüksekliği nedeniyle özelleştirme, tüketim odaklı yaşam sebebiyle mekânın metalaşması, yersizlik duygusu, mekânsal benzeşme, kurallar, yasaklar, izlenme ve katı kontrolle kamusal mekânların terkedilmesi gibi sorunları beraberinde getirmektedir.

Bu problemler pek çok ülkede olduğu gibi Türkiye'deki kamusal mekânlarda da karşımıza çıkmaktadır. Özellikle hızlı kentleşmeyle birlikte 
yasa-dışı gelişen yerleşim alanları yeterli kamusal mekânlardan yoksun olarak büyürken, kent merkezlerinde bazı kamusal mekanların çevrelerindeki özel alanlar tarafından işgal edildiği, tarihi kentsel dokular içindeki kamusal mekânların da gerekli müdahaleler yapılamadığı için zamanla eskime ve köhneme süreçlerine girdiği, mekânsal kalite yetersizliğinin sosyal problemlere de neden olduğu görülmektedir. Bu sorunların kamusal mekânların yönetimindeki eksikliklerden kaynaklandığı düşünülmektedir. Özellikle Türkiye'deki İmar Kanunu'nun ve ilgili yönetmeliklerin, 2014 yılında yayınlanan Mekansal Planlar Yapım Yönetmeliğine kadar sadece parsel bazında yapılaşma koşullarını tanımlaması, kamusal mekan kalitesinden bahsetmemesi, kent planlama ve mimarlık sürecini bütünleştirecek kentsel tasarım ilkelerini, tasarım ve uygulama araçlarını tanımlamaması ülkemizde kamusal mekân kalitesinin yetersizliğine neden olmuştur. Halbuki gelişmiş ülkelerde yaşanabilir, kaliteli, doğal çevreye ve tarihi dokuya uyumlu, yenilikçi kamusal mekânlar tasarlayabilmek için çeşitli ölçek ve türlerde kentsel tasarım araçları kullanıldığı görülmektedir. Bu araçlar kamusal mekânların kalitesinin arttırılması ve özgün kimliğin korunması için makro ölçekten mikro ölçeğe kadar yazılı-görsel tasarım kriterlerini ve uygulama detaylarını barındırmakta, böylece kamusal mekânlardaki gelişmenin kontrolü sağlanabilmektedir (Yener Metin, 2020).

Kamusal mekânlarda kalitenin gerekliliğini ve önemini savunan bu çalışma, hem uluslararası hem de ulusal ölçekte çeşitli raporlar, anlaşmalar ve planlardan kaynaklanan yasal dayanakları temel almıştır. Avrupa Kentsel Şartı'nda kaliteli bir mimari ve fiziksel çevrenin bir kentli hakkı olduğu belirtilmiştir (Council of Europe, 1992). Sürdürülebilir Kalkınma İçin 2030 Gündeminde, kentleri ve yerleşim yerlerini, özellikle kamusal mekânları herkesi kucaklayan, güvenli, güçlü ve sürdürülebilir kılmak gerektiği ifade edilmiştir (United Nations, 2015). Yeni Kentsel Gündemde ise, kentin sosyo-ekonomik işlevinin gerçekleşmesini sağlayan bir unsur olarak kamusal mekânların herkese açık, güvenli ve kaliteli olması, sosyal etkileşime, iktisadi faaliyetlere ve kültürel deneyime hizmet etmesi gerektiği belirtilmiştir (United Nations, 2017). Ulusal ölçekte Dokuzuncu Kalkınma Planı Yerleşme- Şehirleşme Özel İhtisas Komisyonu Raporunda, yaşam kalitesinin sağlanmasında yerleşme ve/veya tasarım öğesi ölçeğinde tasarım rehberleri oluşturulması gerektiği belirtilmiştir (Devlet Planlama Teşkilatı, 2007). Onuncu Kalkınma Planı'nda da kent mimarisinin ve peyzajın insan üzerindeki etkisi göz önünde bulundurularak, yapılacak kentsel tasarımların ve imar planlarının peyzaja, şehrin dokusuna, estetiğine ve kimliğine katkı sağlamasına özen gösterilmesi gerek- 
tiği vurgulanmıştır (Onuncu Kalkınma Planı, 2013). Bayındırlık ve İskan Bakanlığı tarafından hazırlanan Bütünleşik Kentsel Gelişme Stratejisi Eylem Planı'nda yerleşmelerin mekân ve yaşam kalitesinin artırılması başlığı altında, kent kimliğini korumak ve geliştirmek hedefiyle kent kimliğine ilişkin araştırmalar yapılması, özgün mimari, doku ve mekânsal özelliklerin tespit edilmesi, var olan ve yeni gelişen alanların kimliğinin geliştirilmesi için tasarım ilkelerinin oluşturulması, tasarım rehberlerinin hazırlanması gerektiği belirtilmiştir (Bayındırlık ve İskan Bakanlığı, 2010). 2014 yılında yayınlanan Mekansal Planlar Yapım Yönetmeliğinde ise, kentsel tasarım projesinin tanımı yapılmış, kentsel tasarım projelerine dair esaslar altında mekânsal planlama sistematiği içerisinde uygulamaya yönelik kllavuz ve tavsiye niteliğinde kararları içerecek şekilde kentsel tasarım rehberlerinin hazırlanabileceği ifade edilmiştir (Mekansal Planlar Yapım yönetmeliği, 2014). Ayrıca 2015 yılında Çevre ve Şehircilik Bakanlığı'nın desteğiyle Mimar Sinan Güzel Sanatlar Fakültesi kentsel tasarım rehberlerinin hazırlanması konusunda bir proje yapmıştır. Proje sonucunda Türkiye'deki planlama sistemi ile kentsel tasarımın nasıl entegre edilebileceği ve kentsel tasarım rehberlerinin nasıl kullanılabileceği ortaya konmuş, belediyeler için kentsel tasarım rehberi hazırlama el kitapları hazırlanmıştır (Çevre Şehircilik Bakanlığı, 2021).

Bu noktada çalışmanın amacı; Türkiye'deki kamusal mekân kalitesinin arttırılmasında yurtdışında kullanılan kentsel tasarım araçlarından nasıl faydalanılabileceğini ortaya koymak ve Türkiye'de kamusal mekânlara yönelik geliştirilebilecek bir tasarım rehberi için temel başlıkları ve ilkeleri tanımlamaya çalışmaktadır. Makalede incelenecek araştırma soruları şunlardır:

- Kamusal mekân kalitesini oluşturan ölçütler ve bileşenler nelerdir?

- Kamusal mekân kalitesinin sağlanmasında hangi kentsel tasarım araçları kullanılabilir?

- Kamusal mekânların kalitesini arttırmak için geliştirilecek bir tasarım rehberinde yer alması gereken tasarım ilkeleri nelerdir?

Çalışmanın, Çevre ve Şehircilik Bakanlığı'nın desteklediği kentsel tasarım rehberlerinin hazırlanması projesinden farklı olarak, kamusal mekân kalitesine yönelik tasarım rehberlerine odaklanması, kamusal mekanların tasarımı/iyileştirilmesi konusundaki eksikliği gidermek adına bir başlangıç noktası olması hedeflenmiştir. Ülkemizde kentsel tasarımın teorik ve pratik altyapısı yasal-yönetsel açıdan yeni gelişmekte olduğundan, yapılan çalışmanın ileride yapılacak kamusal mekân tasarım ve uygulamalarında kaynak olabileceği düşünülmektedir. 


\section{Kamusal Mekânda Kalite Kriterleri ve Mekânsal Kaliteyi Sağlamada Kentsel Tasarım Araçlarının Rolü}

En yalın tanımıyla şartlara uygunluk olarak ifade edilen kalite, bir ürün veya hizmetin kullanıma uygunluk derecesi ve gerekli tüm ihtiyaçları karşılamaya ilişkin kriterler bütünüdür (Crosby, 1996). Pek çok alanda kullanılan kalite kavramı, kent ve mekânla ilgili çalışmalarda da ele alınarak yeni kavramlar ve kaliteyle ilişkili kriterler oluşturulmuştur. Bunlardan biri, bireyin fiziksel sağlığı, psikolojik durumu, özgürlük seviyesi, sosyal ilişkileri ve yaşadığı çevrenin başlıca özellikleriyle etkileşimleri gibi çok sayıdaki etkenle ilişki içerisinde şekillenen, karmaşık ve geniş bir kavram olan yaşam kalitesidir (World Health Organization, 1995). Yaşam kalitesine mekân boyutunun eklenmesiyle, kentlerde yaşam kalitesini yansıtan ölçütlerin ya da göstergelerin belirlenmesi konusu gündeme gelmiştir. Kent, semt ve mahalle ölçeğinde çeşitlenebilen, öznel ve nesnel göstergelerin bir arada kullanılmasına yönelik bir eğilimin hâkim olduğu bu alanda sosyal göstergelere göre değişkenlerin analizi, mekânları kıyaslayan ekonomik indekslerin oluşturulması ya da yerleşmenin objektif özeliklerinin yanı sıra, kullanıcıların yaşadıkları mekânla ilgili algılarına dayalı çalışmalar yer almaktadır (Evans, 1994; Marans, 2017; Salihoğlu ve Türkoğlu, 2019).

Kentsel yaşam kalitesinin sağlanmasında kent ve kentlilerin birbirleriyle etkileşimine olanak veren kamusal mekânlar önemli bir çalışma alanı olarak karşımıza çıkmaktadır. Özelikle kamusal mekân kalitesinin tanımına yönelik pek çok çalışma yapılmıştır. Bu çalışmalarda temel olarak kamusal mekânın ölçülebilir somut nitelikleri ile mekânı deneyimleyen kullanıcıların algıladıkları soyut nitelikler üzerinde durulmuştur (Yener Metin, 2020). Bu makalede kamusal mekânda kalite ölçütleri ve bileşenleri fiziksel, sosyal ve ekonomik boyutlar altında derlenmiştir (Tablo 1). Kamusal mekân kalitesinin sağlanmasında bu üç boyutun dengeli bir şekilde geliştirilmesi ve kamusal mekânların etkin yönetimi büyük önem taşımaktadır. Çalışma mimarlık alanında gerçekleştirildiğinden kamusal mekânda kaliteyle ilgili fiziksel ve sosyal boyuta odaklanılmıştır. Ekonomik boyuta dair ölçütlerin ilgili disiplinlerden uzmanlarla birlikte geliştirilmesi gerektiği düşünülmektedir. 
Tablo 1. Kamusal mekânda kalite boyutları, ölçütleri ve bileşenleri (Yener Metin, 2020 tarafından şu kaynaklardan derlenerek üretilmiştir: Carr, S., Francis, M., Rivlin, L.G. ve Stone., A. M., 1992; Carmona, M., Heath, T., Oc, T. ve Tiesdell, S., 2003; Carmona, M. Magalhães, C. ve Hammond, L., 2008; Congress for New Urbanism, 1993; Demir Kahraman, 2014; DETR ve CABE, 2000; Gehl, 2001; Lynch, 1981; Project for Public Spaces, 2000; Urban Task Force, 1999; Uzgören ve Erdönmez, 2017; Yeang, 2000; Whyte, 1980).

\begin{tabular}{|c|c|c|c|c|}
\hline FİİKSEL & & SOSYAL & & EKONOMIK \\
\hline Ölçütler & Bileşenler & Ölçütler & Bileşenler & Ölçütler \\
\hline $\begin{array}{l}\text { Biçimsel } \\
\text { çeşitlilik ve } \\
\text { uygunluk } \\
\end{array}$ & $\begin{array}{l}\text { devamlllık ve ritim, } \\
\text { kapalılık, düzen }\end{array}$ & $\begin{array}{l}\text { Algilana } \\
\text { bilirlik }\end{array}$ & $\begin{array}{l}\text { estetik, ölçek, okunabilirlik, } \\
\text { tanımlı olma, yönlenme }\end{array}$ & \\
\hline $\begin{array}{l}\text { Ekolojik } \\
\text { verimlilik }\end{array}$ & $\begin{array}{l}\text { uygun arazi kullanımı, } \\
\text { doğal kaynak } \\
\text { korunumu, enerji } \\
\text { verimliliği, geri } \\
\text { dönüşüm }\end{array}$ & Anlam & $\begin{array}{l}\text { yerel bağlam, evrensellik, } \\
\text { imaj, kimlik, tarihsellik ve } \\
\text { kalıcılık, sembolik değer }\end{array}$ & $\begin{array}{l}\text { Sunulan } \\
\text { hizmet } \\
\text { çeşitliliği }\end{array}$ \\
\hline \multirow[t]{2}{*}{$\begin{array}{l}\text { Erişile } \\
\text { bilirlik }\end{array}$} & \multirow{2}{*}{$\begin{array}{l}\text { hareket kolaylığı ve } \\
\text { devamlılığı, mekân ve } \\
\text { bağlantı sürekliliği, } \\
\text { yaya-taşıt ayrımı ve } \\
\text { yaya önceliği }\end{array}$} & Deneyim & $\begin{array}{l}\text { aidiyet ve bağ kurma, } \\
\text { hissetme, hoşnutluk, merak } \\
\text { ve keşfetme }\end{array}$ & \multirow{2}{*}{$\begin{array}{l}\text { Yerel/ } \\
\text { kentsel } \\
\text { ekonomik } \\
\text { katkı }\end{array}$} \\
\hline & & $\begin{array}{l}\text { Aktif ve } \\
\text { pasif } \\
\text { etkileşim }\end{array}$ & $\begin{array}{l}\text { görsel süreklilik, aktivite } \\
\text { çeşitliliği, kullanıcı çeşitliliği, } \\
\text { cazibe, kent manzaraları }\end{array}$ & \\
\hline Esneklik & $\begin{array}{l}\text { adapte olabilirlik, çok } \\
\text { amaçlı kullanım, } \\
\text { zamansal kullanım } \\
\text { çeşitliliği }\end{array}$ & Güvenlik & $\begin{array}{l}\text { suç ve kazalara karşı koruma, } \\
\text { trafik denetimi }\end{array}$ & \\
\hline $\begin{array}{l}\text { İşlevsel } \\
\text { çeşitlilik ve } \\
\text { uygunluk }\end{array}$ & $\begin{array}{l}\text { karma kullanım, } \\
\text { kentsel bağlama } \\
\text { uygunluk }\end{array}$ & Kontrol & $\begin{array}{l}\text { kişiselleştirme, kullanım } \\
\text { alışkanlığı, sahiplenme }\end{array}$ & \\
\hline Konfor & $\begin{array}{l}\text { Ergonomiklik, } \\
\text { geçirgenlik, görsel } \\
\text { uygunluk, iklimsel } \\
\text { şartlara uygunluk, } \\
\text { teknik yeterlilik, } \\
\text { optimum yoğunluk, } \\
\text { sağlık şartlarına } \\
\text { uygunluk }\end{array}$ & $\begin{array}{l}\text { Psikolojik } \\
\text { konfor }\end{array}$ & $\begin{array}{l}\text { mahremiyet, güvende } \\
\text { hissetme, dinlenme }\end{array}$ & $\begin{array}{l}\text { Yerel } \\
\text { istihdam } \\
\text { olanakları }\end{array}$ \\
\hline
\end{tabular}

Kamusal mekânların yönetiminde kurumsal koordinasyon ile yerel katılım, finansal kaynakların sağlanması ve planlama- mimarlıkla ilgili mevzuatın ve uygulama araçlarının varlığı en temel gereklilikler olarak karşımıza çıkmaktadır. Bu bağlamda kamusal mekânların yönetiminde farklı ülkelerde çeşitli amaç ve ölçeklere uygun kentsel tasarım araçlarının geliştirildiği görülmektedir. Kentsel tasarım araçları, tasarım ve uygulama aşamalarındaki aksaklıklara cevap aramak için hazırlanan dokümanlardır. Bu araçlar, kentsel bağlamı anlama, topluluğun katılımını teşvik etme, kentsel tasarım konuları- 
nın anlaşılmasını arttırma, amaçlanan tasarım sonuçlarını tanımlama, tasarım süreçlerini oluşturma, insanları ve kaynakları organize etmede yardımcı olabilmektedir (Ministry for the Environment Manatü Mö Te Taiao, 2006).

Kentsel tasarım araçları, sürecin her aşamasında yer alan kişilerin, kentsel tasarım meseleleri hakkında ortak bir dil oluşturarak konuşmasına ve birlikte daha etkili bir şekilde çalışmasına yardımcı olmak için geliştirilir. Uygun araç ve tekniklerin mantıklı bir şekilde seçilmesi ve uygulanması kentlerde yüksek kalitede mekânlar elde etmemize yardımcı olur (Ministry for the Environment Manatü Mö Te Taiao, 2006). Kamusal mekân kalitesini sağlamada yaygın olarak kullanılan araçlar Tablo 2`de hitap ettikleri kentsel alan ölçekleri, yasal statüleri ve amaçları açısından incelenmiştir.

Tablo 2. Kamusal mekânların planlama ve tasarımında kullanılan kentsel tasarım araçları (Yener Metin, 2020 tarafından şu kaynaklardan derlenerek üretilmiştir: CABE, 2006; Carmona, 2017; Çevre ve Şehircilik Bakanlığı, 2016a; Çevre ve Şehircilik Bakanlı̆̆ı, 2016b; DETR ve CABE, 2000; Ministry for the Environment Manatü Mö Te Taiao, 2006; Punter, 1999; Yeang, 2000)

\begin{tabular}{|c|c|c|c|}
\hline $\begin{array}{l}\text { KENTSEL } \\
\text { TASARIM } \\
\text { ARAÇLARI }\end{array}$ & ÖLÇEK & $\begin{array}{l}\text { YASAL } \\
\text { STATÜ }\end{array}$ & AMAÇ \\
\hline $\begin{array}{l}\text { Kentsel Tasa- } \\
\text { rım Çerçeveleri }\end{array}$ & $\begin{array}{l}\text { kent, mahalle, ka- } \\
\text { musal mekân }\end{array}$ & yasal & $\begin{array}{l}\text { Politikaları, alana özgü girişimleri yönlendirmek ve } \\
\text { karmaşık projelere yol gösterecek esnek bir vizyon } \\
\text { oluşturmak }\end{array}$ \\
\hline $\begin{array}{l}\text { Kentsel Tasa- } \\
\text { rım Rehberleri }\end{array}$ & $\begin{array}{l}\text { kent, mahalle, ka- } \\
\text { musal mekân }\end{array}$ & $\begin{array}{l}\text { yasal ve tav- } \\
\text { siye niteli- } \\
\text { ğinde }\end{array}$ & $\begin{array}{l}\text { Tasarım ilkelerini hazırlamak, sorunlara yönelik çö- } \\
\text { züm yolları sunmak ve sürece dahil olan herkesle ile- } \\
\text { tişim bağı oluşturmak }\end{array}$ \\
\hline $\begin{array}{l}\text { Sokak Peyzaj1 } \\
\text { Stratejisi }\end{array}$ & $\begin{array}{l}\text { kent, mahalle, ka- } \\
\text { musal mekân, so- } \\
\text { kak }\end{array}$ & yasal & $\begin{array}{l}\text { Açık kamusal mekânların tasarımında bulunması ge- } \\
\text { reken görsel nitelikleri, yönetim ve bakım gereksi- } \\
\text { nimlerini ve planlama politikasını tanımlamak }\end{array}$ \\
\hline Örnek Kitabı & $\begin{array}{l}\text { mahalle, kamusal } \\
\text { mekân, sokak, } \\
\text { açı alan, bina }\end{array}$ & yasal & $\begin{array}{l}\text { Mimari kütlelerdeki, cephelerdeki, malzemelerdeki } \\
\text { karakteri düzenlemek }\end{array}$ \\
\hline Tasarım Özeti & $\begin{array}{l}\text { kent, mahalle, ka- } \\
\text { musal mekân }\end{array}$ & $\begin{array}{l}\text { tavsiye nite- } \\
\text { liğinde }\end{array}$ & $\begin{array}{l}\text { Kentsel tasarım projesi için fiziksel tasarım kriterlerini } \\
\text { ve sonuçların belirlemek }\end{array}$ \\
\hline Tasarım Kodu & $\begin{array}{l}\text { mahalle, kamusal } \\
\text { mekân, bina }\end{array}$ & $\begin{array}{l}\text { tavsiye nite- } \\
\text { liğinde }\end{array}$ & $\begin{array}{l}\text { Detaylı çözüm önerileri oluşturup, kamusal } \\
\text { mekânları iyileştirmek }\end{array}$ \\
\hline $\begin{array}{l}\text { Kamu Sanatı } \\
\text { Stratejisi }\end{array}$ & kamusal mekân & yasal & Kentlerde sanatı teşvik etmek \\
\hline $\begin{array}{l}\text { Teknik Rehber- } \\
\text { lik Notu }\end{array}$ & $\begin{array}{l}\text { kamusal mekân, } \\
\text { sokak, meydan, } \\
\text { açık alan, kıyı } \\
\text { alanı }\end{array}$ & yasal & $\begin{array}{l}\text { Sokak mobilyası, bordür, kaldırım ve peyzaj eleman- } \\
\text { ları gibi temel unsurların tasarımını ayrıntılı bir şe- } \\
\text { kilde tasarlamak }\end{array}$ \\
\hline
\end{tabular}

Özetle, yurtdışında kamusal mekân kalitesinin sağlanmasında genel yerleşime yönelik veya yere özel, yasal statülü veya tavsiye niteliğinde, kural koyucu veya performans odaklı, makro ölçekten, mikro ölçeğe kadar tasarım 
kriterleri tanımlayan kentsel tasarım araçlarının geliştirildiği ve kullanıldığı görülmüştür. Tablo 2'de ifade edildiği gibi kentsel tasarımda kullanılan araçlar yerin özelliklerine ve yapılacak çalışmanın amacına göre farklı türlerde olabilir. Bu çalışmada kamusal mekanların geliştirilmesinde kentsel tasarım araçları içinde en yaygın olarak kullanılan kentsel tasarım rehberlerine odaklanılmıştır. Tasarım rehberleri, çeşitli konulara ilişkin tasarım ilkeleri setleri oluşturan, bunları açıklayan ve örneklendiren, tasarımda yapılan genel hataları tanımlayan ve bunlardan kaçınmaya yardım eden, yerel otoritenin mülk sahipleriyle ilişkilerinde tutarlılık sağlayan, müzakere için bir temel oluşturan, yerel otoritenin hem kendi içinde hem de geliştirme sürecinde yer alan herkesle iletişim kurması konusunda yükümlülük getiren belgeler olarak kullanılmaktadır (DETR ve CABE, 2000).

\section{Yöntem}

Kamusal mekân kalitesinin sağlanmasında kentsel tasarım araçlarının rolünü anlayabilmek için alan çalışması kapsamında farklı ülkelerde geliştirilmiş tasarım araçları (özellikle rehberler) incelenmiştir. Her ülkenin planlama-tasarım politikalarındaki farklılıklar tasarım araçları açısından çeşitlilik oluşturmaktadır. Bu amaçla Avrupa'dan üç (Birleşik Krallık- Edinburgh, Bath, Blyth), Avustralya'dan bir (Tonsley), Asya'dan bir (Çin- Hong Kong), Amerika'dan iki (Amerika-San Francisco, Kanada-Cambridge) kentten örnek kentsel tasarım araçları (5 rehber, 1 örnek kitabı (2 cilt), 1 kentsel tasarım protokolü) seçilmiştir. Bunlar, ülkenin yasal planlama-kentsel tasarım politikaları içindeki yerleri, diğer rehberlerle ilişkileri, hedef kitleleri, statüleri, kapsamları, tasarım ve uygulama kriterleri açısından analiz edilmiştir. Bu araçlarda kamusal mekânlarda kalitenin fiziksel ve sosyal boyutuna yönelik hangi bileşenlerin ve tasarım ilkelerinin öne çıtı̆̆̆ tespit edilmiştir. İncelenen rehberlere ve kentlere ait tanıtım bilgileri aşağıdaki Tablo 3'de yer almaktadir. 
Tablo 3. Çalışma kapsamında incelenen kentsel tasarım araçları (Yener Metin, 2020)

\begin{tabular}{|c|c|c|c|c|c|c|c|}
\hline & \multicolumn{3}{|c|}{ Avrupa } & \multirow{2}{*}{$\begin{array}{l}\begin{array}{l}\text { Avus } \\
\text { tralya }\end{array} \\
\text { Avus } \\
\text { tralya }\end{array}$} & \multirow{2}{*}{$\begin{array}{l}\text { Asya } \\
\text { Çin }\end{array}$} & \multicolumn{2}{|c|}{ Amerika } \\
\hline Ülke & İskoçya & İngil & & & & Kanada & Amerika \\
\hline Kent & $\begin{array}{l}\text { Edin } \\
\text { burgh }\end{array}$ & Bath & Blyth & Tonsley & Hong Kong & $\begin{array}{l}\text { Cambrid } \\
\text { ge, } \\
\text { Ontario }\end{array}$ & $\begin{array}{l}\text { San } \\
\text { Francisco }\end{array}$ \\
\hline Rehber & $\begin{array}{l}\text { Edin } \\
\text { burgh } \\
\text { Design } \\
\text { Guidan } \\
\text { ce }\end{array}$ & $\begin{array}{l}\text { Pattern } \\
\text { Book } \\
1-2 \\
\text { Public } \\
\text { Realm } \\
\text { Framework } \\
\text { Techical \& } \\
\text { operational } \\
\text { guidance }\end{array}$ & $\begin{array}{l}\text { Urban } \\
\text { Design } \\
\text { Guide } \\
\text { and } \\
\text { Public } \\
\text { Realm } \\
\text { Strategy }\end{array}$ & $\begin{array}{l}\text { Urban } \\
\text { Design } \\
\text { Protocol } \\
\text { Urban } \\
\text { Form \& } \\
\text { Public } \\
\text { Realm }\end{array}$ & $\begin{array}{l}\text { Hong Kong } \\
\text { Planning } \\
\text { Standards } \\
\text { and } \\
\text { Guidelines } \\
\text { Urban } \\
\text { Design } \\
\text { Guidelines }\end{array}$ & $\begin{array}{l}\text { Down } \\
\text { town } \\
\text { Urban } \\
\text { Design } \\
\text { Guide } \\
\text { lines }\end{array}$ & $\begin{array}{l}\text { San } \\
\text { Francisco } \\
\text { Urban } \\
\text { Design } \\
\text { Guide } \\
\text { lines }\end{array}$ \\
\hline Nüfus & 482.005 & 88.859 & 37.339 & 167.000 & 7.392 .000 & 129.920 & 853.173 \\
\hline $\begin{array}{l}\text { Kentin } \\
\text { niteliği }\end{array}$ & $\begin{array}{l}\text { Tarihi } \\
\text { ve yeni } \\
\text { gelişen } \\
\text { başkent }\end{array}$ & $\begin{array}{l}\text { Nehir } \\
\text { kıyısında } \\
\text { tarihi kent } \\
\text { merkezi }\end{array}$ & $\begin{array}{l}\text { Deniz ve } \\
\text { nehir } \\
\text { kıyısında } \\
\text { tarihi kent } \\
\text { merkezi }\end{array}$ & $\begin{array}{l}\text { Deniz } \\
\text { kıyısında } \\
\text { tarihi kent }\end{array}$ & $\begin{array}{l}\text { Çok sayıda } \\
\text { adadan } \\
\text { oluşan yeni } \\
\text { gelişen kent }\end{array}$ & $\begin{array}{l}\text { Nehir } \\
\text { kiyisında } \\
\text { yeni } \\
\text { gelişen } \\
\text { kent }\end{array}$ & $\begin{array}{l}\text { Deniz } \\
\text { kiyisında } \\
\text { yeni } \\
\text { gelişen } \\
\text { kent }\end{array}$ \\
\hline $\begin{array}{l}\text { Sektör } \\
\text { ler }\end{array}$ & $\begin{array}{l}\text { Tarım, } \\
\text { Balık } \\
\text { çlık, } \\
\text { içki ve } \\
\text { tekstil }\end{array}$ & $\begin{array}{l}\text { Turizm } \\
\text { (termal) }\end{array}$ & $\begin{array}{l}\text { Turizmsa } \\
\text { nayi ve } \\
\text { ulaşım }\end{array}$ & $\begin{array}{l}\text { Turizm } \\
\text { tarim ve } \\
\text { sanayi }\end{array}$ & $\begin{array}{l}\text { Ticaret, } \\
\text { ulaşım ve } \\
\text { turizm }\end{array}$ & $\begin{array}{l}\text { Turizm } \\
\text { ve tarım }\end{array}$ & $\begin{array}{l}\text { Turizm } \\
\text { ve sanayi }\end{array}$ \\
\hline
\end{tabular}

\section{Bulgular}

Bu bölümde Edinburgh, Bath, Blyth, Tonsley, Hong Kong, Cambridge ve San Francisco için geliştirilmiş kentsel tasarım araçları incelenmiştir. Bu araçların amaçları, kapsamları ve kamusal mekânlarla ilgili öne çıkan yönleri kısaca şöyle özetlenebilir:

Edinburgh Tasarım Rehberliği (Şekil 1), kentteki yeni gelişim alanlarına odaklanarak, yerel planlardaki politikalara nasıl uyulacağı konusunda rehberlik etmeyi amaçlamıştır. Tasarım sürecinde göz önünde bulundurulması gereken temel fikirleri açıklamış, tasarım ve erişim için gereklilikleri belirlemiştir. Rehberde bağlam, yer yapma ve tasarım başlığı altında yeni gelişmelere yönelik üst ölçekli tasarım ilkeleri belirlenmiş, ayrıca yeni binalara yönelik tasarım kriterleri ve kamusal yerlerin tasarımında peyzaj, biyo-çeşitlilik ve su kıyıları hakkında kriterler tanımlanmıştır. Ek olarak sokakların tasarımına yönelik detaylı bir rehberlik oluşturulmuştur (The City of Edinburgh Council, 2020). Rehber, temel olarak kamusal mekânlara yönelik tasarım fikirlerini kentin zengin tarihi dokusuna dayandırmış ve kent karakterini destekleyici 
nitelikte ilkeler tanımlamıştır. Yapılacak değişikliklerin ve yenilemelerin kültürel mirasa saygılı olmasına önem verilmiş, cephe tasarımları, binaların boyutları, bitkilendirme ve yere özgü kent mobilyası seçimleriyle hem tarihi dokuya ve yerel bağlama uygun, hem de kent yapısını ve kullanıc ihtiyaçlarını destekleyici yönlendirmeler yapılmıştır (Yener Metin, 2020).

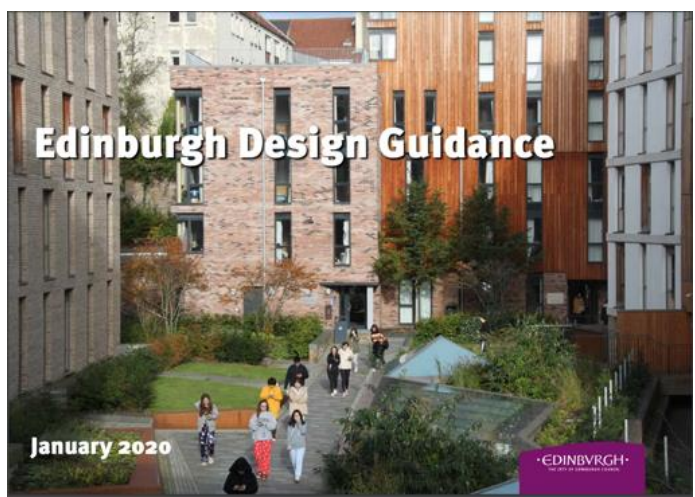

Şekil 1. Edinburgh Tasarım Rehberliği (The City of Edinburgh Council, 2020).

Bath Örnek Kitapları (Şekil 2-3), kentin mirasını korumak, aynı zamanda sürdürülebilir, ilerici ve yaşanabilir bir kentin gerekliliklerine uyum sağlamak için kamunun nasıl hissetmesi gerektiğine dair kapsamlı bir açıklama sunmayı amaçlamıştır. İki cilt olan kitaplardan birincisi (kamusal mekan çerçevesi); Bath'in kamusal mekânlarını, insanların birbirleriyle etkileşime girdiği caddeleri, meydanları ve geçitleri, kentin mimarisini ve manzarasını anlatmış ve bu yerleşimlerin tasarımını destekleyen ilkeleri belirlemiştir. İkinci ciltte (teknik ve uygulamaya yönelik rehber) bu ilkeler, kent merkezinde sokakların düzeninin nasıl sağlanacağını, malzeme kalitesine ilişkin beklentileri, detaylandırma ve bakım yapmak için uygulanması gerekenleri tarif eden pratik talimatlara dönüşmüştür (Bath \& North East Somerset Council, 2015a, 2015b). Yaya erişimi üzerine kurulu kamusal mekânların beraberinde güçlü bir sokak ağını getireceği düşüncesiyle çerçevede erişilebilirlik ölçütü öne çımıştır. Bina kütlelerinin ve sokakların oranını yapılı çevreye ve insan ölçeğine göre değerlendiren çerçeve, mevcut sokak mirasını korumuş ve yeni tasarımların da buna uygun nitelikte olması gerektiğini ifade etmiştir. Kullanıcıların kamusal mekândan beklentilerini destekleyici tasarım hedefleri oluşturulmuştur (Yener Metin, 2020). 

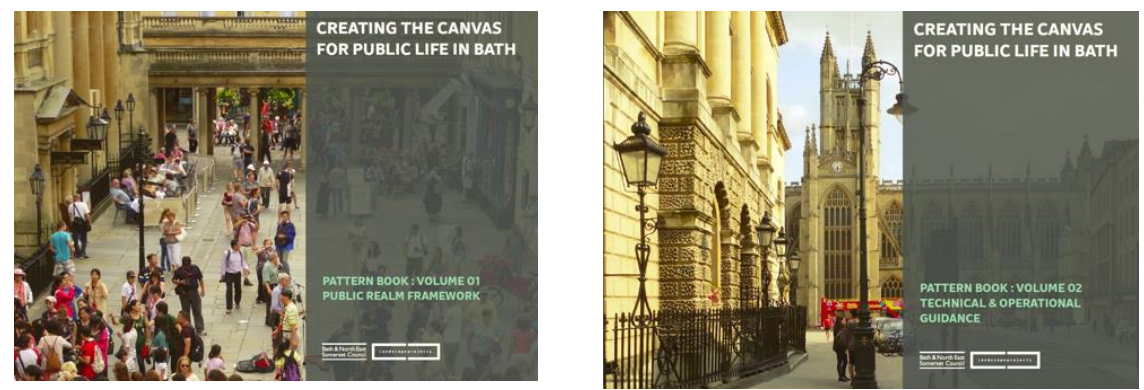

Şekil 2-3. Bath Örnek Kitapları: Kamusal Mekân Çerçevesi, Teknik \& Uygulamaya Yönelik Rehberlik (Bath \& North East Somerset Council, 2015a, 2015b)

Blyth Kentsel Tasarım Rehberi ve Kamusal Mekân Stratejisinde (Şekil 4) kenti bütüncül bir şekilde düşünerek kamusal mekânları iyileştirmek ve teşvik etmek temel amaç olmuştur. Rehber, yapılan tasarımlar ile Blyth kent merkezinin görsel imajını korumak, caddeleri ve sokakları ziyarete açı, cazip kamusal mekânlar haline getirmek düşüncesi üzerine kurulmuştur. Rehber üç aşamada kurgulanmıştır. Birinci aşamada; Blyth kent merkezinin tarihi gelişimi ve kent merkezinin karakteri incelenmiş, mevcut sorunları analiz edilmiştir. İkinci aşamada; rehberin vizyonu, stratejisi ve temel prensipleri belirlenmiş, kent merkezi için genel çerçeve oluşturulmuş ve özel karakteristik alanlar saptanmıştır. Üçüncü aşamada; yerel halk ile etkili iletişim için konsey buluşmaları yapılmış ve rehber için finansal altyapı düzenlenmiştir. Bu sayede, nitelikli bir kent merkezi için kentsel tasarım ilkeleri belirlenmiştir (Blyth Valley Borough Council, 2008). Kentin fiziksel konumu ve insan ihtiyaçları tasarım kriterlerini biçimlendirmiştir. Erişilebilirlik ve sosyal etkileşim için tarihi dokunun kamusal mekânda hissedilmesini ve yaşamasını amaçlayarak sokak peyzajını, kent siluetini, görsel sürekliliği koruyucu yönlendirmeler yapılmıştır (Yener Metin, 2020). 


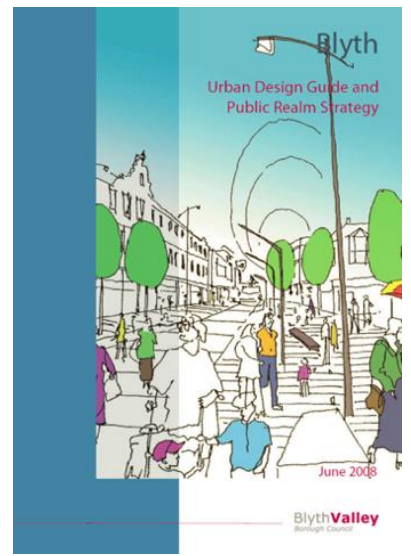

Şekil 4. Blyth Kentsel Tasarım Rehberi ve Kamusal Mekân Stratejisi (Blyth Valley Borough Council, 2008)

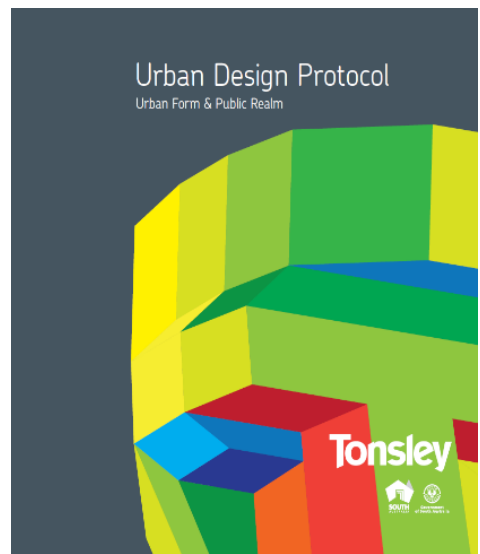

Şekil 5. Tonsley Kentsel Tasarım Protokolü: Kentsel tasarım \& kamusal mekân (Government of South Australia,

Tonsley Kentsel Tasarım Protokolü (Şekil 5), daha alt ölçekteki alanlar için hazırlanan el kitaplarını yönlendiren üst ölçekli bir tasarım aracıdır. Bu protokol, iyileştirme alanına dahil olan kamusal mekân, sokak peyzajı ve peyzaj, cephe ve arayüz, detaylar ve malzemeler gibi kentsel tasarım öğelerinin hedeflerini açıklamayı amaçlamıştır. Belgede sırasıyla kentsel tasarımın önemi, kamusal mekân kalitesine etkisi ve analizler sonucu ortaya çıkan ilkeler üzerinde durulmuştur. Tonsley öncelikle Adelaide kent ölçeğinde yorumlanmış, ardından yerel ölçeğe inilerek sahip olduğu sosyal yapı ve mimari doku üzerinden tanımlanmıştır. Bölgede bulunan binalar ve kamusal mekânlar incelenerek kalite kriterleri için yönlendiriciler tanımlanmıştır (Government of South Australia, 2019). Temel olarak kamusal mekânın aktif ve canlı olması prensibine dayanan protokol, en iyi kamusal mekân kalitesini oluşturmayı amaçlayarak, tüm kullanıcılara, geniş zaman dilimlerinde farklı seçeneklerle kamusal mekânı deneyimleme imkanı sunmuştur (Yener Metin, 2020). 

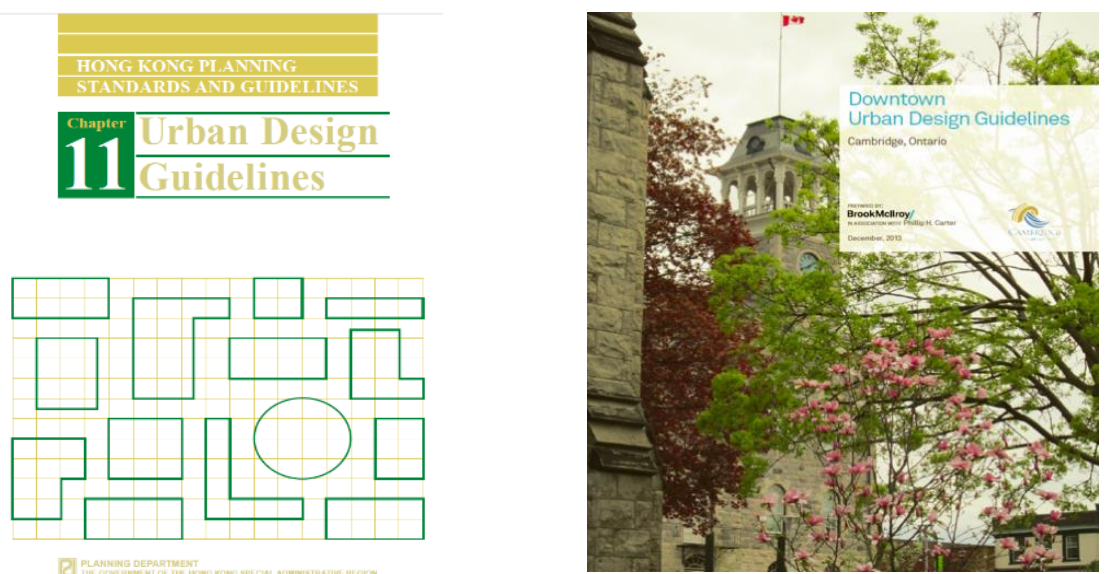

Şekil 6. Hong Kong Planlama Standartları ve Rehberleri: Kentsel Tasarım Rehberleri (The Government of the Hong Kong Special Administative Region, 2020).

Şekil 7. Cambridge Kent Merkezi Kentsel Tasarım Rehberleri (Carter, 2013).

Hong Kong Kentsel Tasarım Rehberi (Şekil 6), Hong Kong'da dünya standartlarında bir kent imajı yaratmak ve yapılı çevrenin kalitesini arttırmak için hazırlanmış, estetik ve fonksiyonel yönden daha iyi bir ortam oluşturmayı amaçlamıştır. Rehberde Hong Kong'un kompakt ve dinamik bir kent olduğu vurgulanmış ve yüksek kaliteli, sürdürülebilir bir ortam oluşturmak için kentsel tasarım kavram ve ilkeleri üzerinde durulmuştur (The Government of the Hong Kong Special Administative Region, 2020). Özellikle yaya erişimi ve konforunun, odak noktaların ve yönlendirici peyzaj tasarımlarının gerekliliği vurgulanmıştır. Yaya hareketlerini temel alan rehber bu bağlamda; açık alanları, bina konumlarını, sokak ağını, kentsel öğeleri ve peyzaj elemanlarını birlikte kurgulamıştır. Kullanıcı odaklı hareket ederek kamusal mekânda optimum kaliteyi sağlamayı hedeflemiştir (Yener Metin, 2020).

Cambridge Kentsel Tasarım Rehberi (Şekil 7), Cambridge merkezindeki kültür mirası binalar, yeni binalar, sokak peyzajı ve yönlendirme tabelaları ile ilgili yönergeler sunmuştur. Rehber, Cambridge için kapsamlı ve uygulanabilir bir vizyon oluşturmayı, yenilemeye uygun ve mirasla uyumlu öneriler geliştirmeyi amaçlamıştır. Ayrıca kent merkezindeki kamusal mekân kalitesini arttırmak ve yerel yönetim uygulamalarını desteklemek için kamusal mekânların koruma önceliklerini ve canlandırma seçeneklerini belirlemiştir. Rehber, giriş, çalışma alanı, kontrol listesi gibi bölümlerden oluşmuş ve detaylı olarak tasarım yönergelerine yer vermiştir. Cambridge kamusal mekânlarına ve bina yapısına genel bir bakış getirmiş ve önerilen sokak peyzajı ana 
planını tanımlamıştır. Miras binalarına yapılacak tadilat ve ilaveler, yeni binalar, tabelalar, yaya alanları, parklar ve sokak manzaraları için ilkeler sunmuştur (Carter, 2013). Kamusal mekânda insan ölçeğinin öneminin belirtildiği rehberde, tasarımlar sokak algısını koruyacak ve destekleyecek nitelikte tanımlanmıştır.

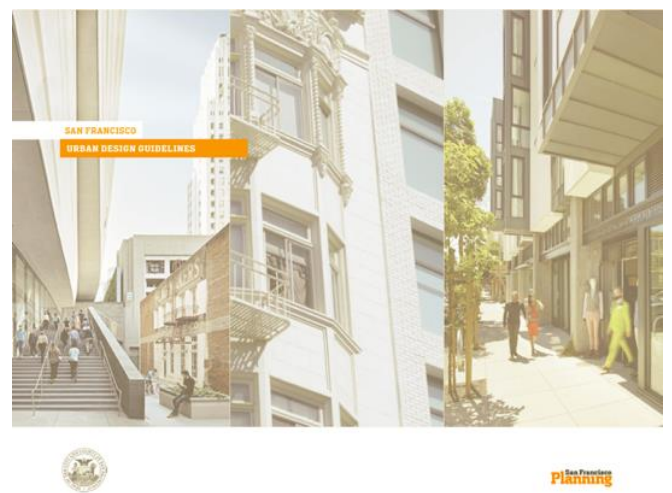

Şekil 8. San Francisco Kentsel Tasarım Rehberi (San Francisco Planning Department, 2018).

San Francisco Kentsel Tasarım Rehberleri (Şekil 8) ile yapı dokusunun, sokakların ve diğer kamusal mekânların kalitesini yükseltmek ve San Francisco'yu daha yaşanabilir bir kent haline getirmek amaçlanmıştır. Ayrıca iç mekân faaliyetleri ve kamusal mekân arasındaki bağlantıyı güçlendiren binalarla, insanlara daha çok seçenek oluşturan bir kentsel yaşam deneyimi sunmak istenmiştir. "Tasarlanarak inşa edilen çevre, kentin kültürel değerlerinin fiziksel bir sonucudur" düşüncesi ile rehber oluşturulmuştur (San Francisco Planning Department, 2018). Rehberde, yüksek yoğunluklu ve karma kültüre sahip kamusal mekânlar için tasarım fikirleri verilmiştir. Bina yerleşimleri, boyutları ve sokak üzerindeki etkisi ile detaylar veren rehber, güvenliği doğrudan sağlayan öneriler sunmuştur. Kamusal mekânın temelinde insan olduğu düşüncesinden hareketle, kullanıcı ihtiyaçlarına yönelik fikirler ön planda yer almıştır (Yener Metin, 2020).

Çalışmada ayrıca incelenen rehberlerde yer alan kamusal mekânlarla ilgili tasarım kriterlerinin, literatür araştırmasıyla ortaya koyulan kamusal mekân kalite kriterleri ve bileşenleriyle ne kadar örtüştüğü tespit edilmiştir. İncelenen bütün rehberlerde fiziksel boyut içinde tanımlanan 6 ölçüt ve 22 bileşenin; cepheler, binalar, formlar, dış mekanlar, aydınlatma, ulaşım, bitkilendirme, malzemeler, kent mobilyaları, sokaklar, zemin katlar, su elemanları, 
altyapı gibi kamusal mekanı oluşturan farklı elemanlar için geliştirilmiş önerilerde yer aldığı görülmüştür. Yine incelenen bütün rehberlerde sosyal boyut içinde tanımlanan 7 ölçüt ve 28 bileşenin; cepheler, malzemeler, su elemanları ve bitkilendirme, kent mobilyaları ve sanat eserleri, aydınlatmalar, binalar, kentsel imgeler, dış mekanlar, malzemeler ve detaylar, aktivite türleri, zemin katlar, sokaklar, kullanım zamanları gibi kamusal mekanı oluşturan farklı elemanlar için geliştirilmiş önerilerde tanımlandığı belirlenmiştir.

Sonuç olarak tüm rehberlerde uygulama alanları farklılık gösterse de, kamusal mekânda fiziksel ve sosyal boyuta ilişkin kalitenin sağlanması amacryla çeşitli ilkelerin, kriterlerin, önerilerin ve yönlendiricilerin bulunduğu görülmüştür. Böylece çalışma kapsamında incelenen yedi kentsel tasarım aracı örneği üzerinden Türkiye'de kamusal mekânların kalitesini arttırmak için geliştirilecek bir tasarım rehberinde yer alması önerilen başlıklar ve tasarım ilkeleri oluşturulmuştur.

\section{Tartışma ve Sonuç}

Kamusal mekânlar farklı kesimlerden insanları bir araya toplayan, ihtiyaçlarını karşılayacak tüm imkanları sunan ve toplumsal bütünlüğü oluşturan kentsel mekânlardır. Kent kültürünü yaşatmak ve günlük aktiviteleri gerçekleştirmek için kamusal yaşamda büyük öneme sahip olan kamusal mekânların kent içerisinde yeterli sayıda ve kalitede tasarlanması gerekir.

Çalışma kapsamında, ülkemizde kamusal mekân kalitesinin sağlanmasında tasarım ve uygulama aşamasında yönlendirici olması için yurtdışındaki kentsel tasarım araçlarından nasıl faydalanılabileceği araştırılmış, bu araçlarda kamusal mekân kalitesini sağlayan ilkeler, hedefler, kriterler tespit edilmiştir. İncelenen örneklerde görüldüğü gibi kentsel tasarım araçlarında yer alan ilkeler ve yönlendirmeler kamusal mekan kalitesinin sağlanmasında olumlu sonuçlar vermektedir. Bu araçlardaki tasarım ilkeleri, farklı ölçek ve özelliklerdeki kamusal mekanlara uygulanabilir şekilde tanımlanmıştır. Böylece kapsama ve ihtiyaca uygun kentsel tasarım araçları ile kaliteli kamusal mekanlar elde edilmesi hedeflenmiştir.

Çalışma sonucunda, ülkemizde kamusal mekân tasarımında kullanılabilecek ve bağlama göre geliştirilebilecek taslak bir rehber oluşturulmuştur. $\mathrm{Bu}$ rehberde kamusal mekânlarda kalite ölçüt ve bileşenlerini sağlamak için kamusal mekânı oluşturan farklı uygulama alanlarına yönelik tasarım ilkeleri yer almaktadır (Tablo 4.1, 4.2). 
Tablo 4.1. Kamusal mekânlar için önerilen kalite kriterleri, bileşenleri, uygulama alanları ve ilkeleri (Fiziksel boyut) (Yener Metin, 2020)

\begin{tabular}{|c|c|c|c|}
\hline \multicolumn{4}{|c|}{ KAMUSAL MEKÂNDA KALİTENIN FİİKSEL BOYUTU } \\
\hline Ölç & Bileşenler & Uygulama alanı & ílkeler \\
\hline \multirow{4}{*}{ 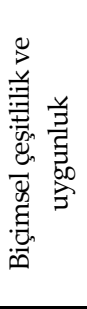 } & \multirow{2}{*}{$\begin{array}{l}\text { Devamlilık } \\
\text { ritim }\end{array}$} & Cepheler & \multirow{2}{*}{$\begin{array}{l}\text { Bina yüksekliklerini ve cephedek } \\
\text { boşluklari/hareketleri dengeli ve düzenli } \\
\text { bir şekilde devam ettirmek }\end{array}$} \\
\hline & & Binalar & \\
\hline & Düzen & Formlar & $\begin{array}{l}\text { Kamusal mekân sınırlarını belirgin bir } \\
\text { şekilde tanımlamak }\end{array}$ \\
\hline & Kapalılık & & $\begin{array}{l}\text { Bina kütleleri ve boşlukları arasında } \\
\text { denge kurarak kullanıcıların mekânı } \\
\text { daha iyi algılamasını sağlamak }\end{array}$ \\
\hline \multirow{10}{*}{ 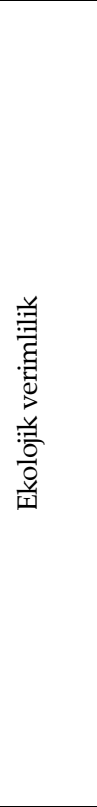 } & \multirow{2}{*}{$\begin{array}{l}\text { Uygun } \\
\text { kullanimı }\end{array}$} & Binalar & \multirow{2}{*}{$\begin{array}{l}\text { Arazi topoğrafyasıyla uyumlu yapılaşma } \\
\text { sayesinde doğal-yapılı çevre arasında } \\
\text { denge sağlamak }\end{array}$} \\
\hline & & Diş mekânlar & \\
\hline & \multirow{4}{*}{$\begin{array}{l}\text { Doğal kaynak } \\
\text { korunumu }\end{array}$} & Binalar & \multirow{2}{*}{$\begin{array}{l}\text { Pasif iklimlendirme sistemlerinden } \\
\text { faydalanmak, hava, su, toprak kalitesini } \\
\text { korumak }\end{array}$} \\
\hline & & Diş mekânlar & \\
\hline & & Aydınlatma & \multirow{2}{*}{$\begin{array}{l}\text { Kamusal mekânlarda yenilebilir enerji } \\
\text { sistemlerinden faydalanmak, temiz } \\
\text { ulaşım sistemlerini-tolu taşımayı- teşvik } \\
\text { etmek, CO2 salınımını azaltmak }\end{array}$} \\
\hline & & Ulaşım & \\
\hline & \multirow[t]{2}{*}{ Enerji verimliliği } & Bitkilendirmeler & \multirow{2}{*}{$\begin{array}{l}\text { Sert - yeşil zemin oranını dengeleyerek } \\
\text { kamusal mekânda isı adası oluşumunu } \\
\text { engellemek, iklime uygun, az su } \\
\text { gerektiren bitkilendirme, dayanıklı zemin } \\
\text { ve cephe kaplamaları seçmek }\end{array}$} \\
\hline & & Malzemeler & \\
\hline & \multirow[t]{2}{*}{ Geri dönüşüm } & Kent mobilyaları & $\begin{array}{l}\text { Kamusal mekânda kullanıcıları geri } \\
\text { dönüşüme teşvik edecek kent mobilyaları } \\
\text { yerleştirmek }\end{array}$ \\
\hline & & Malzemeler & 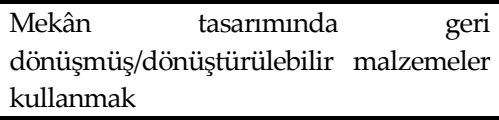 \\
\hline \multirow{4}{*}{ 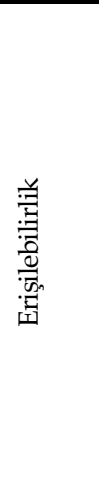 } & \multirow[t]{4}{*}{$\begin{array}{l}\text { Hareket kolaylı̆̆ } \\
\text { ve devamlılı̆ı }\end{array}$} & Aydınlatma & $\begin{array}{l}\text { Sokak ağını, hedef mekâna doğru yapılan } \\
\text { hareketi gösterecek şekilde aydınlatmak }\end{array}$ \\
\hline & & Bitkilendirmeler & $\begin{array}{l}\text { İnsanların hareketlerini zorlaştırmamak } \\
\text { için sert-yumuşak zemin tasarımında } \\
\text { hareket yönlerini ve eğilimlerini göz } \\
\text { önünde bulundurmak }\end{array}$ \\
\hline & & Kent mobilyaları & $\begin{array}{l}\text { Çeşitli kent mobilyalarını (aydınlatmalar, } \\
\text { bilgilendirici ve yönlendirici tabelalar, } \\
\text { banklar) amacına uygun olarak; yayaların } \\
\text { aktif biçimde kullandıkları ağlar üzerinde } \\
\text { konumlandırmak }\end{array}$ \\
\hline & & Malzemeler & $\begin{array}{l}\text { Kullanıcıların yürüme konforuna uygun } \\
\text { zemin malzemeleri kullanmak }\end{array}$ \\
\hline
\end{tabular}




\begin{tabular}{|c|c|c|c|}
\hline & $\begin{array}{l}\text { Mekân } \\
\text { bağlantı } \\
\text { sürekliliği }\end{array}$ & Sokaklar & $\begin{array}{l}\text { Hedef mekâna ulaşmak için farkl } \\
\text { yerlerden gelen ve kademeli olarak } \\
\text { birleşen sokaklar kurgulamak }\end{array}$ \\
\hline & & Diş mekânlar & $\begin{array}{l}\text { Kullanımı arttırmak için kamusal } \\
\text { mekânları birbirleri ile bağlantılı olarak } \\
\text { yerleştirmek }\end{array}$ \\
\hline & & & $\begin{array}{l}\text { Kamusal mekânları kentsel işlevlerle } \\
\text { ilişkili olarak ve hareket ağı üzerinde } \\
\text { kurgulamak }\end{array}$ \\
\hline & $\begin{array}{l}\text { Yaya-yaşıt ayrımı } \\
\text { ve yaya önceliği }\end{array}$ & Diş mekânlar & $\begin{array}{lrrr}\text { Kamusal mekânları } & \text { kent içinde } \\
\text { yürünebilir } & \text { mesafe } & \text { aralıklarında } \\
\text { kurgulamak } & & \\
\end{array}$ \\
\hline & & Sokaklar & $\begin{array}{l}\text { Kullanıcı çeşitliliği düşünülerek; bisiklet } \\
\text { ve yaya yolları ile toplu taşımayı bir } \\
\text { bütün olarak kurgulamak }\end{array}$ \\
\hline & & Kent mobilyaları & $\begin{array}{l}\text { Yaya-taşıt ilişkisini düzenleyecek peyza) } \\
\text { tasarımı yapmak ve yaya önceliğini ifade } \\
\text { edecek işaret levhaları kullanmak }\end{array}$ \\
\hline \multirow{7}{*}{ 曾 } & Adapte olabilirlik & Diş mekânlar & $\begin{array}{l}\text { Gelecekteki ihtiyaçlara uyum } \\
\text { sağlayabilecek, değişebilir-dönüşebilir, } \\
\text { gerektiğinde } \\
\text { birleştirilebilir mekânlar tasarlamak }\end{array}$ \\
\hline & \multirow[t]{3}{*}{$\begin{array}{l}\text { Çok amaçlı } \\
\text { kullanım }\end{array}$} & Binalar & $\begin{array}{l}\text { İşlevsel açıdan eskiyen binaları yeniden } \\
\text { işlevlendirmek, binalara farklı } \\
\text { zamanlarda aktif olarak kullanılabilecek } \\
\text { işlevler tanımlamak }\end{array}$ \\
\hline & & Diş mekânlar & $\begin{array}{lrr}\text { Aynı anda } & \text { farklı } & \text { etkinliklerin } \\
\text { düzenlenebileceği } & \text { alt } & \text { mekânlar } \\
\text { kurgulamak } & & \\
\end{array}$ \\
\hline & & Kent mobilyaları & $\begin{array}{l}\text { Etkinliklere göre düzenlenebilecek } \\
\text { hareketli kent mobilyalan kullanmak }\end{array}$ \\
\hline & \multirow{3}{*}{$\begin{array}{l}\text { Zamansal } \\
\text { kullanım } \\
\text { çeşitliliği }\end{array}$} & Binalar & $\begin{array}{l}\text { Günün farklı saatlerinde } \\
\text { verebilecek işlevler tanimlamak }\end{array}$ \\
\hline & & Diş mekânlar & $\begin{array}{l}\text { Farklı saatlerde veya yılın farkl } \\
\text { dönemlerinde yapılacak etkinliklere } \\
\text { uygun esnek mekânlar tasarlamak }\end{array}$ \\
\hline & & Kent mobilyaları & $\begin{array}{l}\text { Farklı mevsimlerde ve günün tüm } \\
\text { saatlerinde kullanılabilecek nitelikte kent } \\
\text { mobilyaları seçmek }\end{array}$ \\
\hline \multirow{3}{*}{ 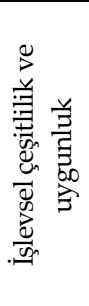 } & \multirow[t]{3}{*}{ Karma kullanım } & Binalar & $\begin{array}{l}\text { Farklı işlevlere sahip binalar (ticaret, } \\
\text { eğitim, idare, kültür vb) tanımlamak }\end{array}$ \\
\hline & & Diş mekânlar & $\begin{array}{l}\text { Farklı ihtiyaçlara aynı anda hizmet veren } \\
\text { ( eğlence, dinlenme, oyun, eğitim vb ) } \\
\text { mekânlar tasarlamak }\end{array}$ \\
\hline & & Zemin katlar & $\begin{array}{l}\text { Zemin katlarda yeme-içme mekânların } \\
\text { ve zengin alışveriş imkanlarını bir arada } \\
\text { kurgulamak }\end{array}$ \\
\hline
\end{tabular}




\begin{tabular}{|c|c|c|c|}
\hline & $\begin{array}{l}\text { Kentsel bağlama } \\
\text { uygunluk }\end{array}$ & Diş mekânlar & $\begin{array}{l}\text { Bulunduğu yerin fiziksel ve sosyal } \\
\text { özelliklerine uygun, yerel halkın yaşam } \\
\text { biçimine ve ihtiyaçlarına uygun kamusal } \\
\text { mekânlar tasarlamak }\end{array}$ \\
\hline & & Binalar & $\begin{array}{l}\text { Kamusal mekânda özgün kentsel dokuya } \\
\text { uygun binalar tasarlamak }\end{array}$ \\
\hline \multirow{16}{*}{$\begin{array}{l}\tilde{o}_{0} \\
\stackrel{0}{0} \\
\underline{1}\end{array}$} & \multirow[t]{4}{*}{ Ergonomiklik } & Cepheler & $\begin{array}{l}\text { Kullanıcıları görsel olarak rahatsız edecek } \\
\text { (parlak) cephe kaplama malzemelerini } \\
\text { kullanmaktan kaçınmak }\end{array}$ \\
\hline & & \multirow[t]{2}{*}{ Malzemeler } & $\begin{array}{l}\text { Yürüme konforu için kullanıcıyı } \\
\text { yormayacak, kullanışlı ve dayanıklı } \\
\text { zemin kaplamaları seçmek }\end{array}$ \\
\hline & & & $\begin{array}{l}\text { İklimsel koşullara uygun (aşırı } \\
\text { 1sınmayan, kaygan olmayan vb.) zemin } \\
\text { kaplamaları seçmek }\end{array}$ \\
\hline & & Kent mobilyaları & $\begin{array}{l}\text { Faaliyetlerin türüne ve süresine uygun } \\
\text { boyutta ve malzemeden üretilmiş kent } \\
\text { mobilyaları seçmek }\end{array}$ \\
\hline & \multirow[t]{3}{*}{ Geçirgenlik } & Binalar & $\begin{array}{l}\text { Bina yüksekliklerini görsel algıyı } \\
\text { engellemeyecek şekilde dengelemek }\end{array}$ \\
\hline & & Bitkilendirme & $\begin{array}{l}\text { Ağaç ve bitki yüksekliklerini görsel } \\
\text { ilişkileri koparmayacak } \\
\text { düzenlemek }\end{array}$ \\
\hline & & Zemin katlar & $\begin{array}{l}\text { Saydam zemin kat cepheleri, vitrin } \\
\text { tasarımları ve dış mekâna taşan } \\
\text { kullanımlar ile kullanıcıların görsel } \\
\text { algısını arttırmak }\end{array}$ \\
\hline & \multirow[t]{3}{*}{ Görsel uygunluk } & Binalar & \multirow{3}{*}{$\begin{array}{l}\text { Kamusal mekânı oluşturan tüm binaları, } \\
\text { mobilyaları ve malzemeleri bütüncül bir } \\
\text { bakış açısıyla, görsel açıdan birbirini } \\
\text { tamamlayacak şekilde tasarlamak }\end{array}$} \\
\hline & & Kent mobilyaları & \\
\hline & & Malzemeler & \\
\hline & \multirow[t]{6}{*}{$\begin{array}{l}\text { İklimsel şartlara } \\
\text { uygunluk }\end{array}$} & Diş mekânlar & $\begin{array}{l}\text { Olumsuziklimsel koşullardan korunmak } \\
\text { için mekânın boyutunu ve kapalılığını } \\
\text { dengede tutmak }\end{array}$ \\
\hline & & Bitkilendirmeler & \multirow{2}{*}{$\begin{array}{l}\text { Ağaçlar, bitkiler ve su } \\
\text { kullanarak mekânda } \\
\text { mikroiklim oluşturmak }\end{array}$} \\
\hline & & Su elemanları & \\
\hline & & Binalar & $\begin{array}{l}\text { Güneşlenmeyi engellememek ve yeterli } \\
\text { hava akışını sağlayabilecek boşluklar } \\
\text { oluşturmak için bina-dış mekân } \\
\text { dengesini sağlamak. }\end{array}$ \\
\hline & & Kent mobilyaları & $\begin{array}{l}\text { Tenteler ve örtüler gibi mobilyalar ile } \\
\text { güneş ve yağış etkisinden korunma } \\
\text { sağlamak }\end{array}$ \\
\hline & & Malzemeler & $\begin{array}{l}\text { Aşırı sıcak iklimlerde emiciliği ve } \\
\text { yansıtıcılığı düşük, bol yağışlı ve soğuk } \\
\text { iklimlerde pürüzlü yüzeye sahip zemin } \\
\text { kaplamaları kullanmak }\end{array}$ \\
\hline
\end{tabular}


Optimum mikroiklim yaratmak için cephe malzemelerinde 1 siyı yansitic malzemeler kullanmamak

\begin{tabular}{|c|c|c|}
\hline \multirow[t]{4}{*}{ Teknik yeterlilik } & Diş mekânlar & $\begin{array}{lll}\text { Sokaklardaki kot farklarını } & \text { hem } \\
\text { merdiven, hem de } & \text { rampa } \\
\text { düzenlemeleriyle çözmek } & \\
\end{array}$ \\
\hline & Altyapı & $\begin{array}{l}\text { Kullanıcı yoğunluğu düşünülerek gerekli } \\
\text { internet, elektrik, temiz ve pis su, yağmur } \\
\text { suyu vb tesisat ve bağlantılarını kurmak }\end{array}$ \\
\hline & Kent mobilyaları & $\begin{array}{l}\text { Kullanıc yoğunluğuna ve ihtiyacına } \\
\text { uygun sayıda ve türde kent mobilyası } \\
\text { kullanmak, sağlam montaj yapmak }\end{array}$ \\
\hline & Cepheler & $\begin{array}{l}\text { Yapı elemanlarını, malzeme ve detayları } \\
\text { doğru uygulamak }\end{array}$ \\
\hline \multirow[t]{3}{*}{$\begin{array}{l}\text { Optimum } \\
\text { yoğunluk }\end{array}$} & Diş mekânlar & $\begin{array}{l}\text { Bina- dış mekân oranının dengeli } \\
\text { olmasını sağlamak }\end{array}$ \\
\hline & Aydınlatmalar & $\begin{array}{l}\text { Ana caddeler ile alt sokaklarda } \\
\text { aydınlatma farkı yaratarak kamusal } \\
\text { mekânları kademelendirmek }\end{array}$ \\
\hline & Bitkilendirmeler & $\begin{array}{l}\text { Doğal- yapılı çevre oranının dengeli } \\
\text { olmasını sağlamak }\end{array}$ \\
\hline \multirow[t]{4}{*}{$\begin{array}{l}\text { Sağlık şartlarına } \\
\text { uygunluk }\end{array}$} & Diş mekânlar & $\begin{array}{l}\text { Her mahallede yürüme mesafesinde/ } \\
\text { yürümeyi teşvik edecek dış } \\
\text { mekânlar/yeşil alanlar/spor alanları } \\
\text { oluşturmak, sosyal mesafe koşullarına } \\
\text { uygun büyüklükte mekânlar tasarlamak }\end{array}$ \\
\hline & Binalar & $\begin{array}{l}\text { Yeşil bina cepheleri ve yeşil çatilar } \\
\text { tasarlamak }\end{array}$ \\
\hline & Kent mobilyaları & $\begin{array}{l}\text { Özellikle oturma elemanlarını sosyal } \\
\text { mesafe koşullarına uygun olarak } \\
\text { yerleştirmek, uygun yerlerde spor aletleri } \\
\text { kullanmak }\end{array}$ \\
\hline & Bitkilendirmeler & $\begin{array}{l}\text { Hava kalitesini arttırmak ve } \mathrm{CO} 2 \\
\text { miktarını azaltmak için bitkilendirmeden } \\
\text { faydalanmak }\end{array}$ \\
\hline
\end{tabular}


Tablo 4.2. Kamusal mekânlar için önerilen kalite kriterleri, bileşenleri, uygulama alanları ve ilkeleri (Sosyal boyut) (Yener Metin, 2020)

\begin{tabular}{|c|c|c|c|}
\hline \multicolumn{4}{|c|}{ KAMUSAL MEKÂNDA KALITENİN SOSYAL BOYUTU } \\
\hline Ölç & Bileşenler & Uygulama alanı & İlkeler \\
\hline \multirow{15}{*}{ 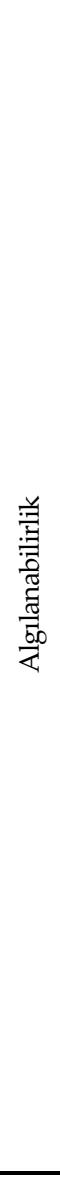 } & \multirow[t]{5}{*}{ Estetik } & Cepheler & $\begin{array}{l}\text { Birbiriyle uyumlu, görsel olarak özgün cepheler } \\
\text { tasarlamak }\end{array}$ \\
\hline & & Malzemeler & $\begin{array}{l}\text { Cephede ve zeminde birbiriyle ve özgün dokuyla } \\
\text { uyumlu malzemeler kullanmak, farklı işlev alanlarını } \\
\text { farklı zemin ve cephe kaplamalarıyla göstermek }\end{array}$ \\
\hline & & $\begin{array}{l}\text { Su elemanlar1 ve } \\
\text { bitkilendirmeler }\end{array}$ & $\begin{array}{l}\text { Özgün dokuya ve iklime uygun peyzaj tasarımı } \\
\text { yapmak }\end{array}$ \\
\hline & & $\begin{array}{l}\text { Kent mobilyaları } \\
\text { ve sanat eserleri }\end{array}$ & $\begin{array}{l}\text { Özgün dokuya uygun kent mobilyaları kullanarak } \\
\text { ortak bir tasarım dili yaratmak, kamusal sanat } \\
\text { eserleriyle güzellik duygusunu yükseltmek }\end{array}$ \\
\hline & & Aydınlatmalar & Özgün cepheleri ve sanat eserlerini aydınlatmak \\
\hline & \multirow[t]{2}{*}{ Ölçek } & Binalar & $\begin{array}{l}\text { Sokak boyunca } \\
\text { dengeleyerek insan ölçeğini korumak }\end{array}$ \\
\hline & & Bitkilendirmeler & $\begin{array}{l}\text { Taşıt yollarını yaya ve bisiklet yollarından ayıran yeşil } \\
\text { bantları görsel sürekliliği engellemeyecek yükseklikte } \\
\text { seçmek }\end{array}$ \\
\hline & \multirow[t]{2}{*}{$\begin{array}{l}\text { Okuna } \\
\text { bilirlik }\end{array}$} & Aydınlatmalar & $\begin{array}{l}\text { Gerekli bina cephelerini, zemin katlarını, yaya-taşıt } \\
\text { izlerini, bitkileri, su elemanlarını ve sanat eserlerini } \\
\text { aydınlatarak kamusal mekânda bütüncül etki } \\
\text { yaratmak }\end{array}$ \\
\hline & & Kentsel imgeler & $\begin{array}{l}\text { Bölgeleri, sınırları, yolları, işaret öğeleri, odak ve } \\
\text { düğüm noktaları kolayca ayırt edilebilen ve bağlamla } \\
\text { bütüncül ilişki kuran kamusal mekânlar tasarlamak }\end{array}$ \\
\hline & \multirow[t]{2}{*}{$\begin{array}{l}\text { Tanımlı } \\
\text { olma }\end{array}$} & Binalar & $\begin{array}{l}\text { İnsan ölçeğinde, ezici etkisi olmayan bina } \\
\text { yükseklikleri tanımlamak }\end{array}$ \\
\hline & & Diş mekânlar & Mekânı sınırları, işlevi, cephesi, zemini ile tarif etmek \\
\hline & \multirow[t]{4}{*}{ Yönlenme } & Binalar & \multirow{4}{*}{$\begin{array}{l}\text { Etkili bina, bitkilendirme ve kent mobilyaları (işaret } \\
\text { levhaları vb) dizilimiyle ve peyzaj tasarımıyla } \\
\text { kullanıcıların hareketlerini yönlendirmek }\end{array}$} \\
\hline & & Bitkilendirmeler & \\
\hline & & Aydınlatmalar & \\
\hline & & Kent mobilyaları & \\
\hline \multirow{6}{*}{ 氶 } & \multirow[t]{4}{*}{$\begin{array}{l}\text { Yerel } \\
\text { bağlam }\end{array}$} & Diş mekânlar & $\begin{array}{l}\text { Öncelikle yerel halkın ihtiyaçlarını karşılayacak, } \\
\text { kültürünü ve yaşam biçimini temsil edecek şekilde } \\
\text { düzenlemek }\end{array}$ \\
\hline & & Bitkilendirmeler & $\begin{array}{l}\text { Peyzaj tasarımında yerel bitkileri ve ağaçları } \\
\text { kullanarak mekânı çevre ile bütünleştirmek }\end{array}$ \\
\hline & & Cepheler & $\begin{array}{l}\text { Cephe tasarımında, kapı ve pencere gibi elemanlarda } \\
\text { ve detay uygulamalarında özgün dokuyu devam } \\
\text { ettirmek }\end{array}$ \\
\hline & & $\begin{array}{l}\text { Malzemeler } \\
\text { detaylar }\end{array}$ & $\begin{array}{l}\text { Zemin ve cephe kaplamalarında yerel malzeme } \\
\text { kullanmak }\end{array}$ \\
\hline & \multirow[t]{2}{*}{$\begin{array}{l}\text { Evren } \\
\text { sellik }\end{array}$} & Diş mekânlar & $\begin{array}{l}\text { Herkese hitap edecek, kamusallık derecesi yüksek } \\
\text { mekânlar tasarlamak }\end{array}$ \\
\hline & & Aktivite türleri & Herkese hitap edecek faaliyet olanakları sunmak \\
\hline
\end{tabular}




\begin{tabular}{|c|c|c|c|}
\hline & \multirow[t]{3}{*}{ İmaj } & Diş mekânlar & Akılda kalıcı, belirgin bir imaj oluşturmak \\
\hline & & Zemin katlar & $\begin{array}{l}\text { Bütüncül bir şekilde kurgulanmış ticari mekânlar } \\
\text { oluşturmak }\end{array}$ \\
\hline & & Malzemeler & $\begin{array}{l}\text { Kamusal mekânı akılda kalıcı hale getirecek cephe ve } \\
\text { zemin malzemeleri seçmek }\end{array}$ \\
\hline & Kimlik & Binalar & $\begin{array}{l}\text { Özgün binalar tasarlayarak her mekânın farklı bir } \\
\text { kimliğe sahip olduğunu göstermek }\end{array}$ \\
\hline & & Malzemeler & $\begin{array}{l}\text { Seçilen malzemeler ve peyzaj tasarımı üzerinden } \\
\text { mekânın geçmişiyle ilişki kurmak }\end{array}$ \\
\hline & Tarihsel & Cepheler & Sokaklarda ve caddelerde geçmişten gelen tarihi izleri \\
\hline & $\begin{array}{l}\text { lik ve } \\
\text { kalıcilık }\end{array}$ & & $\begin{array}{l}\text { korumak ve yeni uygulamaları özgün dokuyu } \\
\text { destekleyici bakış açısıyla tasarlamak }\end{array}$ \\
\hline & & Aktivite türleri & $\begin{array}{l}\text { Kentin kültürel birikimi doğrultusunda yerel halkın } \\
\text { düzenli olarak gercekleştirdiği faaliyetlere uygun } \\
\text { mekânlar tasarlamak }\end{array}$ \\
\hline & & Sokaklar & $\begin{array}{l}\text { Tarihi ve mimari değere sahip yapıları ve doğal } \\
\text { güzellikleri öne çıkaracak, saygılı ve destekleyici } \\
\text { tasarımlar yapmak, yerin ruhunu korumak }\end{array}$ \\
\hline & $\begin{array}{l}\text { Sembo } \\
\text { lik değer }\end{array}$ & Binalar & $\begin{array}{l}\text { Kent için önemli binaların çevresindeki silüeti düşük } \\
\text { tutmak }\end{array}$ \\
\hline & & Diş mekânlar & $\begin{array}{l}\text { Soyut ve somut kültürel değerleri temsil edecek } \\
\text { öğeleri içeren mekânlar tasarlamak }\end{array}$ \\
\hline \multirow{9}{*}{ 胥 } & \multirow[t]{2}{*}{$\begin{array}{l}\text { Aidiyet ve } \\
\text { bağ kurma }\end{array}$} & Sanatsal öğeler & $\begin{array}{l}\text { Kamusal sanat ile kullanıcıların mekânda kendilerine } \\
\text { ait izler/anılar oluşturmasını sağlamak }\end{array}$ \\
\hline & & Diş mekânlar & $\begin{array}{l}\text { Mekânın özgün kimliğini koruyarak, kullanıcının } \\
\text { mekânı yaşamasını, içselleştirmesini, kendisiyle } \\
\text { özdeşleştirmesini sağlamak }\end{array}$ \\
\hline & \multirow[t]{2}{*}{$\begin{array}{l}\text { Hisset } \\
\text { me }\end{array}$} & Binalar & $\begin{array}{l}\text { Özgün dokuyu bozmadan kullanıcıların yerin } \\
\text { ruhunu hissetmesini sağlamak }\end{array}$ \\
\hline & & Bitkilendirmeler & $\begin{array}{l}\text { Mekânda bitkilendirmelere yer vererek kullanıcıların } \\
\text { doğayı deneyimlemesini sağlamak. }\end{array}$ \\
\hline & \multirow[t]{2}{*}{$\begin{array}{l}\text { Hoşnut } \\
\text { luk }\end{array}$} & Diş mekânlar & $\begin{array}{l}\text { Gürültü, koku, kalabalık gibi rahatsız edici durumları } \\
\text { optimum seviyede tutmak }\end{array}$ \\
\hline & & & $\begin{array}{lll}\text { Kullanıcıların ihtiyaçlarını } & \text { huzur } & \text { içinde } \\
\text { karşılamalarını sağlamak } & \end{array}$ \\
\hline & \multirow{3}{*}{$\begin{array}{l}\text { Merak } \\
\text { keşfet } \\
\text { me }\end{array}$} & Sanatsal öğeler & $\begin{array}{l}\text { Kamusal mekânlarda farklı sergiler düzenleyerek } \\
\text { kullanıcıları çekmek }\end{array}$ \\
\hline & & Diş mekânlar & $\begin{array}{l}\text { Farklı tip sokakların birleştiği, toplanmaya ve } \\
\text { ayrılmaya imkan sağlayan odak noktaları oluşturmak }\end{array}$ \\
\hline & & Kent mobilyaları & $\begin{array}{l}\text { Farklı amaçlarla (tırmanma duvarı gibi) kullanılan } \\
\text { kent mobilyaları, kullanıcı etkili cephe tasarımları } \\
\text { kullanmak }\end{array}$ \\
\hline \multirow{3}{*}{ 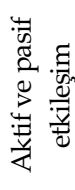 } & \multirow{3}{*}{$\begin{array}{l}\text { Görsel } \\
\text { sürek } \\
\text { lilik }\end{array}$} & Zemin katlar & $\begin{array}{l}\text { Zemin katlarda saydam yüzeyler kullanarak iç-dış } \\
\text { mekân birlikteliği oluşturmak }\end{array}$ \\
\hline & & Bitkilendirmeler & $\begin{array}{l}\text { Görsel sürekliliği bozmayacak ölçekte bitkilendirme } \\
\text { yapmak }\end{array}$ \\
\hline & & Binalar & Kent manzaralarını kapatmamak \\
\hline
\end{tabular}




\begin{tabular}{|c|c|c|c|}
\hline & & Aydınlatmalar & $\begin{array}{l}\text { Geniş saatlerde çeşitli aktivitelere olanak sağlayacak } \\
\text { bütüncül aydınlatma yapmak }\end{array}$ \\
\hline & \multirow[t]{5}{*}{$\begin{array}{l}\text { Aktivite } \\
\text { çeşitli } \\
\text { liği }\end{array}$} & Diş mekânlar & $\begin{array}{l}\text { Farklı etkinliklerin yapıldığı kamusal mekânları } \\
\text { kademeli bir şekilde birbirine bağlamak, işlevine } \\
\text { uygun büyüklükte kamusal mekânlar tasarlamak }\end{array}$ \\
\hline & & Bitkilendirmeler & $\begin{array}{l}\text { Güneşlenme veya gölgede dinlenme olanaklarını bir } \\
\text { arada sunacak bitkilendirme kullanmak }\end{array}$ \\
\hline & & Zemin katlar & $\begin{array}{l}\text { Zemin katlarda farklı ihtiyaçlara yönelik ticari } \\
\text { mekânlar ve yeme-içme yerleri oluşturmak }\end{array}$ \\
\hline & & Kent mobilyaları & $\begin{array}{l}\text { Bekleme, yaslanma, oturma gibi eylemlere uygun } \\
\text { mobilyalar seçmek }\end{array}$ \\
\hline & & Malzemeler & $\begin{array}{l}\text { Sert zemin- yumuşak zemin birlikteliğini dengeli } \\
\text { kurgulamak }\end{array}$ \\
\hline & \multirow[t]{4}{*}{$\begin{array}{l}\text { Kullanıcı } \\
\text { çeşitliliği }\end{array}$} & Aktivite türleri & $\begin{array}{l}\text { Farklı kullanıcı gruplarına yönelik aktiviteleri yakın } \\
\text { mesafede konumlandırmak }\end{array}$ \\
\hline & & $\begin{array}{l}\text { Kullanim } \\
\text { zamanları }\end{array}$ & $\begin{array}{l}\text { Geniş saat dilimlerinde farklı kullanıcı gruplarını } \\
\text { aktif olarak bir araya getirmek }\end{array}$ \\
\hline & & Diş mekânlar & $\begin{array}{l}\text { Duyusal iletişime olanak veren, optimum genişlikte } \\
\text { mekân tasarımları yapmak }\end{array}$ \\
\hline & & Kent mobilyaları & $\begin{array}{l}\text { Kullanıcıların iletişimine olanak sağlayacak mesafede } \\
\text { mobilyaları yerleştirmek }\end{array}$ \\
\hline & \multirow[t]{2}{*}{ Cazibe } & Aktivite türleri & $\begin{array}{l}\text { Sergi, dans, söyleşi, dinleti gibi insanları dahil eden } \\
\text { aktiviteler düzenlemek }\end{array}$ \\
\hline & & Kent mobilyaları & $\begin{array}{l}\text { Çocuk oyun elemanları, konser platformları, sergi } \\
\text { standları, oturma ve izleme elemanları gibi kent } \\
\text { mobilyaların bir arada kullanmak }\end{array}$ \\
\hline & \multirow{2}{*}{$\begin{array}{l}\text { Kent } \\
\text { manzara } \\
\text { ları }\end{array}$} & Binalar & \multirow{2}{*}{$\begin{array}{l}\text { Binaları konumlandırırken ve peyzaj tasarımı } \\
\text { yaparken kentin sahip olduğu doğal ve yapılı çevre } \\
\text { manzaraların kapatmamak, kamusal mekândan } \\
\text { manzaranın hissedilmesini ve deneyimlenmesini } \\
\text { sağlamak }\end{array}$} \\
\hline & & Bitkilendirmeler & \\
\hline \multirow{6}{*}{ 尝 } & \multirow{6}{*}{$\begin{array}{l}\text { Suç ve } \\
\text { kazalara } \\
\text { karş1 } \\
\text { koruma }\end{array}$} & Diş mekânlar & $\begin{array}{l}\text { Boşlukta olma hissi vermeyecek, dengeli büyüklükte } \\
\text { mekânlar tasarlamak }\end{array}$ \\
\hline & & & $\begin{array}{l}\text { Aşırı kalabalık kamusal mekânlara boş ve tenha } \\
\text { olabilecek sokakları bağlamak yerine, kullanıcı } \\
\text { yoğunluğunun kademeli olarak azaldığı bir sokak ağı } \\
\text { tasarlamak }\end{array}$ \\
\hline & & Binalar & $\begin{array}{l}\text { Çevredeki binaları günün tüm saatlerinde kullanıma } \\
\text { uygun olacak şekilde karma bir şekilde } \\
\text { işlevlendirmek }\end{array}$ \\
\hline & & Sokaklar & $\begin{array}{l}\text { Sokağa cephesi olan binalarda balkon ve geniş } \\
\text { pencereler kullanarak, zemin katlarda bulunan } \\
\text { dükkanların geniş vitrinleri ile görsel denetim } \\
\text { oluşturmak }\end{array}$ \\
\hline & & & $\begin{array}{l}\text { Teknoloji desteği ile sokaklarda kamera, sensörlü } \\
\text { aydınlatma, çağrı butonları vb. ile denetim sağlamak }\end{array}$ \\
\hline & & Aydınlatmalar & $\begin{array}{l}\text { Sokakları yeterince aydınlatarak günün her saatinde } \\
\text { güvenli kullanım imkanı sunmak }\end{array}$ \\
\hline
\end{tabular}




\begin{tabular}{|c|c|c|c|}
\hline & \multirow[t]{3}{*}{$\begin{array}{l}\text { Trafik } \\
\text { denetimi }\end{array}$} & Malzemeler & $\begin{array}{l}\text { Yaya ve taşıt yolu ayrımını algılamayı kolaylaştırmak } \\
\text { ve yaya geçişlerini belirginleştirmek için dikkat çekici, } \\
\text { sınır belirtici malzemeler (döşeme kaplaması, boyası } \\
\text { vs.) kullanmak }\end{array}$ \\
\hline & & Kent mobilyaları & $\begin{array}{l}\text { Yaya kullanımına açı sokaklarda taşıt hareketlerini } \\
\text { kontrol etmek ve sürücüleri uyarmak için } \\
\text { bilgilendirme ve yönlendirme tabelaları yerleştirmek }\end{array}$ \\
\hline & & Bitkilendirmeler & $\begin{array}{l}\text { Yaya ve taşıt yolu ilişkisini kesmeyecek yükseklikte } \\
\text { bitkilendirme yapmak }\end{array}$ \\
\hline \multirow{7}{*}{ 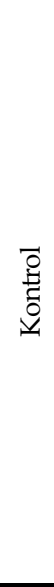 } & \multirow[t]{2}{*}{$\begin{array}{l}\text { Kişiselleş } \\
\text { tirme }\end{array}$} & Kent mobilyaları & $\begin{array}{l}\text { Mekânda kişilerin rahat hissedeceği ve } \\
\text { mahremiyetini koruyacağı seçimler yapmasına } \\
\text { imkan verecek işlevde ve tasarımda kent mobilyaları } \\
\text { kullanmak }\end{array}$ \\
\hline & & Diş mekânlar & $\begin{array}{l}\text { Kullanıcılara bireysel ve grup olarak kullanacak farkl } \\
\text { alt mekânlar sunmak, kullanıcı gruplarının mekânı } \\
\text { kendi ihtiyaçları doğrultusunda düzenlemelerine } \\
\text { imkan verecek esneklikte tasarlamak }\end{array}$ \\
\hline & \multirow{2}{*}{$\begin{array}{l}\text { Kullanim } \\
\text { alışkan } \\
\text { liğ1 }\end{array}$} & Aktivite türleri & $\begin{array}{l}\text { Periyodik etkinlikler düzenleyerek kullanıcıları } \\
\text { mekâna çekmek }\end{array}$ \\
\hline & & Zemin katlar & $\begin{array}{l}\text { Zemin katlara ticaret işlevi vererek, işletme sahipleri } \\
\text { ile kullanıcıların iletişim kurmasını sağlamak }\end{array}$ \\
\hline & \multirow{3}{*}{$\begin{array}{l}\text { Sahiplenm } \\
\text { e }\end{array}$} & Binalar & \multirow{3}{*}{$\begin{array}{l}\text { Kullanıcılar için önemli bellek öğelerini (mekânları, } \\
\text { sanat eserlerini, ağaçları vb) yerinde koruyarak } \\
\text { yaşatmak }\end{array}$} \\
\hline & & Bitkilendirmeler & \\
\hline & & Sanat eserleri & \\
\hline \multirow{9}{*}{ 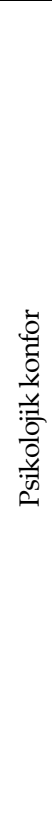 } & \multirow[t]{3}{*}{$\begin{array}{l}\text { Mahremiy } \\
\text { et }\end{array}$} & Bitkilendirmeler & $\begin{array}{l}\begin{array}{l}\text { Oturma, yürüme, buluşma } \\
\text { kullanıcları diğerlerinden } \\
\text { bitkilendirme yapmak }\end{array} \\
\text { kismen aktivitelerde } \\
\text { ayıran }\end{array}$ \\
\hline & & Zemin katlar & $\begin{array}{l}\text { İç-dış ilişkisini dengeli bir şekilde sağlayacak } \\
\text { şeffaflıkta/opaklıkta zemin katlar tasarlamak }\end{array}$ \\
\hline & & Kent mobilyaları & $\begin{array}{l}\text { Mobilyaları kullanıcıların aralarında yeterli mesafe } \\
\text { kalacak şekilde yerleştirmek }\end{array}$ \\
\hline & \multirow[t]{3}{*}{$\begin{array}{l}\text { Güvende } \\
\text { hissetme }\end{array}$} & Diş mekânlar & $\begin{array}{l}\text { Kullanıciya esnek ve rahat ortam sunan, ancak } \\
\text { sinırları tanımlı mekânlar sunmak }\end{array}$ \\
\hline & & & $\begin{array}{l}\text { Farklı aktiviteler arasında nitelikli boşluklar bırakarak } \\
\text { kullanıcıya güven ortamı oluşturmak }\end{array}$ \\
\hline & & Binalar & $\begin{array}{l}\text { Cephe genişlikleri ve yükseklikleri çok fazla olan } \\
\text { binalar insanda ezici bir etki oluşturduğundan bina } \\
\text { tasarımında insan ölçeğini aşmamak }\end{array}$ \\
\hline & \multirow[t]{3}{*}{ Dinlenme } & $\begin{array}{l}\text { Su elemanları ve } \\
\text { bitkilendirmeler }\end{array}$ & $\begin{array}{l}\text { Su elemanları ve yeşil doku ile rahatlatıcı bir ortam } \\
\text { yaratmak }\end{array}$ \\
\hline & & Kent mobilyaları & $\begin{array}{l}\text { Sokaktaki insan yoğunluğuna göre belirli mesafelerle } \\
\text { oturma elemanları yerleştirmek }\end{array}$ \\
\hline & & Malzemeler & $\begin{array}{l}\text { Sert zemine ek olarak yumuşak zemin oluşturarak } \\
\text { kullanıcilara yere oturma, dinlenme, uzanma } \\
\text { olanakları sağlamak }\end{array}$ \\
\hline
\end{tabular}


Özetle, Tablo 4.1'de kamusal mekânda fiziksel kaliteyi sağlamak için tanımlanan biçimsel çeşitlilik ve uygunluk, ekolojik verimlilik, erişilebilirlik, esneklik, işlevsel çeşitlilik ve uygunluk, konfor bileşenleri altında farklı uygulama alanlarına yönelik 56 ilke tanımlanmıştır. Tablo 4.2'de ise kamusal mekânda sosyal kaliteyi sağlamak için tanımlanan algılanabilirlik, anlam, deneyim aktif ve pasif etkileşim, güvenlik, kontrol, psikolojik konfor bileşenleri altında farklı uygulama alanlarına yönelik 76 ilke oluşturulmuştur. Bununla birlikte, bu çalışmada tanımlanan ilkelerin, pandemi sonrasında değişen yaşam biçimleri ve kullanıcı beklentileri, her kentin/toplumun kendine özgü nitelikleri ve yerel bağlamsal özellikleri dikkate alınarak yorumlanması ve yere özel olarak geliştirilmesi gerekmektedir.

Diğer yandan Türkiye'de kentsel tasarım konusunda henüz gelişmekte olan yasal altyapı ve sınırlı pratikler kamusal mekan kalitesinin sağlanmasını zorlaştırmaktadır. Dolayısıyla yurtdışındaki kentsel tasarım araçlarını ülkemiz şartlarına göre uyarlayarak Türkiye'ye özgü tasarım araçlarını geliştirmek gerekmektedir. Tasarım araçları sayesinde mevcut kalitesiz kamusal mekanlar iyileştirilerek dönüştürülecek, yeni kamusal mekanlar kalite kavramını temel alarak tasarlandığı için nitelikli çevreler elde edilecektir. Bu noktada öncelikle kentsel tasarım araçlarının kamusal mekandaki kaliteyi artttrıcı etkisi kabul edilmeli ve bu araçların ivedilikle geliştirilmesi için gereken adımlar bir an önce atılmalıdır. Bu kapsamda, kentsel tasarım araçlarının hazırlanmasında ve uygulanmasında yasal altyapının geliştirilmesi ve yerel yönetimin desteklenmesi gerekmektedir. Yasal olarak temellendirilmiş ve uygulanması teşvik edilmiş kentsel tasarım araçları, kamu kuruluşları ve sivil topluluklar tarafindan yapılan tasarımlarda da yönlendirici olacak ve kamusal mekan kalitesini teşvik edecektir.

Sonuç olarak, ülkemizde kaliteli kamusal mekânların nasıl üretilebileceğine dair taslak bir rehber sunan bu çalışmanın farklı konumlarda, ölçeklerde ve türlerde kamusal mekânların geliştirilmesinde ve yönetiminde uzmanlara ve yerel yönetimlere yol göstereceği, ayrıca Covid 19 pandemisiyle birlikte artan kaliteli kamusal mekân gereksiniminin sağlanmasına katkı sunacağ düşünülmektedir. 


\section{Extended Abstract}

\section{How Can We Benefit from Urban Design Tools to Increase Public Space Quality?}

\author{
S. Nur Yener Metin \\ ORCID: 0000-0002-1021-899X
}

\author{
Sibel Polat \\ ORCID: 0000-0003-4380-0457
}

Management is an important issue for the quality of public spaces. According to Carmona (2010a, 2010b), under-management cause neglection, dereliction, insecurity, traffic pressure, low spatial quality, lack of access and activities in public spaces, while over-management cause problems such as privatization of public spaces for security or due to high maintenance costs, commodification of public spaces due to consumption-oriented society, lack of sense of place, homogeneity of public spaces, and abandonment of public spaces because of strict rules, prohibitions, monitoring and control.

These problems are encountered in public spaces in Turkey as well as in many countries. While the illegal residential areas, which have developed with rapid urbanization, expand without enough public spaces, many public spaces in the city centres are invaded by private spaces or cars, and some public spaces within the historical urban textures become obsolete over time because of thelack of necessary interventions. It is thought that the lack of the management of public spaces created poor-quality public spaces in many cities. In particular, the Zoning Law (1985) and its Regulations in Turkey did not mention about the quality of public spaces and principles of urban design and did not define any design and implementation tools that would integrate the urban planning and architectural design processes until 2014 when the Regulation for the Preparation of Spatial Plans were approved.

Nevertheless, this study, which claims the necessity and importance of quality in public spaces, is based on the legal references arising from various reports, agreements and plans on both international and national scales. Especially, the 
Integrated Urban Development Strategy and Action Plan (2010) was the first legal document that emphasized the need for urban design and design guidelines to increase public space quality and to conserve urban identity. In addition, in 2015, with the support of the Ministry of Environment and Urbanization, Mimar Sinan Fine Arts University made a project on the preparation of urban design guidelines. As a result of the project, it was revealed how urban design can be integrated with the planning system in Turkey and how urban design guidelines can be prepared and used by municipalities.

Today, in many developed countries, it is seen that various types of urban design tools are used to design innovative public spaces that are lively, high qualified, compatible with the natural environment and historical texture. These tools contain written-visual design criteria and implementation details from macro scale to micro scale in order to increase the quality of public spaces and protect the original urban identity, so that the development of public spaces can be controlled (Yener Metin, 2020).

At this point, the aim of the study is to reveal how the urban design tools can be used to increase the quality of public spaces in Turkey and to define the main topics and principles for a design guideline that can be developed for public spaces in Turkey. The research questions to be explored in the article are:

- What are the criteria and components that form the quality of public space?

- Which urban design tools can be used to ensure the quality of public space?

-What are the design principles that should be included in a design guideline to be developed to increase the quality of public spaces?

In order to understand the role of urban design tools in ensuring the quality of public space, design tools (especially design guidelines) used in different countries were examined within the scope of the case study. The differences in the planning-design policies of each country create diversity in terms of design tools. For this purpose, three tools from Europe (United Kingdom- Edinburgh, Bath, Blyth), one from Australia (Tonsley), one from Asia (China-Hong Kong), two from America (America-San Francisco, Canada-Cambridge), a total of seven urban design tools (5 guidelines, 1 sample book ( 2 volumes), 1 urban design proto$\mathrm{col}$ ) were selected from the cities. These tools were analyzed in terms of their role in the legal planning-urban design policies of the country, their relations with other guidelines, their target groups, their status, scopes, design and implementation criteria. It was determined which components and design principles for the physical and social dimension of quality in public spaces emerged in these tools. 
As a result of the study, a draft guideline which can be developed for different kind of public spaces was created. In this guideline, there are design principles for different elements of the public space to provide quality criteria and components in public spaces.

To ensure the physical quality in public spaces, 56 principles were defined for the different elements of public space to provide typological variety and fitting, ecological efficiency, accessibility, flexibility, mixed-use and physical comfort. To ensure social quality in public spaces, 76 principles were created for the different elements of public space to develop perceptibility, meaning, experience, active and passive interaction, security, control, psychological comfort. However, the principles defined in this study need to be interpreted and developed locally by taking into account the changing lifestyles and user expectations after the pandemic, the unique characteristics of each city/society, and local contextual characteristics.

Since the theoretical and practical infrastructure of urban design in our country is newly developing in terms of legal-administrative dimensions, it is thought that this study can be a source for future public space design and implementation and will contribute to the need for high-quality public spaces, as their importance become more apparent with the Covid 19 pandemic.

\section{Kaynakça/References}

Bath \& North East Somerset Council. (2015a). Pattern book volume 1: public realm framework. Erişim adresi: https://www.bathnes.gov.uk/sites/default/files/sitedocuments/Planning-and-Building-Control/Planning-Policy/Evidence-Base/UrbanDesign-Landscape-and-Heritage/bath_pattern_book_part_1.pdf

Bath \& North East Somerset Council. (2015b). Pattern book volume 2: technical and operational guidance. Erişim adresi: https://www.bathnes.gov.uk/sites/default/files/sitedocuments/Planning-and-Building-Control/Planning-Policy/Evidence-Base/Urban-Design-Landscape-and-Heritage/bath_pattern_book_part_2.pdf

Bayındırlık ve İskan Bakanlı̆̆ı. (2010). Bütünleşik kentsel gelişme stratejisi eylem plan (KENTGES 2010-2023). Erişim adresi: https://webdosya.csb.gov.tr/db/kentges/editordosya/kentges_tr.pdf

Blyth Valley Borough Council. (2008). Blyth urban design guide and public realm strategy. Erişim adresi: https://www.northumberland.gov.uk/NorthumberlandCountyCouncil/media/Planning-and-Building/Conservation/DG-Blyth-Urban-Design-and-Public-Realm.pdf

CABE. (2006). Preparing design codes: a practice manual. London: Riba Publishing. Erişim adresi: https://assets.publishing.service.gov.uk/government/uploads/system/uploads/attachment_data/file/7623/152675.pdf 
Carmona, M., Heath, T., Oc, T. ve Tiesdell, S. (2003). Public places urban spaces, the dimensions of urban design. Oxford: Architectural Press.

Carmona, M. Magalhães, C. ve Hammond, L. (Der.) (2008). Public space: the management dimension. New York: Routledge.

Carmona, M. (2010a). Contemporary public space: critique and classification, part one: Critique. Journal of Urban Design, 15:(1), 123-148. doi: https://doi.org/10.1080/13574800903435651

Carmona, M. (2010b). Contemporary public space, part two: Classification, Journal of Urban Design, 15:(2), 157-173. doi: https://doi.org/10.1080/13574801003638111

Carmona, M. (2017). The formal and informal tools of design governance. Journal of Urban Design, 22 (1), 1-36. doi: https://doi.org/10.1080/13574809.2016.1234338

Carr, S., Francis, M., Rivlin, L.G. ve Stone., A. M. (1992). Public space. New York: Cambridge University Press.

Carter, P. (2013). Downtown urban design guidelines. Erişim adresi: https://www.cambridge.ca/en/build-invest-grow/resources/Downtown-Urban-Design-Guidelines.pdf

Congress for New Urbanism. (1993). Charter for the new urbanism. Erişim adresi: https://www.cnu.org/who-we-are/charter-new-urbanism

Council of Europe. (1992). Avrupa kentsel şartı. Erişim adresi: http://www.mimarlarodasiankara.org/?id=964

Crosby, P.B. (1996). Quality is still free: the art of making quality certain. Newyork: Mc Graw Hill.

Mekansal Planlar Yapım Yönetmeliği. (2014, 14 Haziran). Resmi gazete (Sayı 29030). Erişim adresi: https://www.resmigazete.gov.tr/eskiler/2014/06/20140614-2.htm

Çevre Şehircilik Bakanlığı. (2016a). Kentsel tasarım rehberleri cilt I. Ankara: İncekara Matbaacılık. Erişim adresi: https://webdosya.csb.gov.tr/db/mpgm/editordosya/file/Kentsel\%20Tasarim/Kentsel\%20Tasarim\%20Rehberleri/KENTSEL\%20TASARIM\%20REHBERLERI_Cilt1.pdf

Çevre Şehircilik Bakanlığı. (2016b). Kentsel tasarım rehberleri cilt II. Ankara: İncekara Matbaacılik. Erişim adresi: https://webdosya.csb.gov.tr/csb/dokumanlar/mpgm0056.pdf

Çevre Şehircilik Bakanlığı. (2021). Kentsel tasarım rehberleri. Erişim adresi: https://mpgm.csb.gov.tr/kentsel-tasarim-rehberleri-i-82334

DETR ve CABE. (2000). By design. urban design in the planning system: towards better practice. Erişim adresi: https://www.designcouncil.org.uk/sites/default/files/asset/document/by-design_0.pdf

Demir Kahraman, M. (2014). İnsan ihtiyaçları ve mekânsal elverişlilik kavramları perspektifinde yaşanilırlık olgusu ve mekânsal kalite. Planlama. 24(2), 74-84. doi: https://dx.doi.org/10.5505/planlama.2014.29591

Devlet Planlama Teşkilatı. (2007). Dokuzuncu kalkınma planı (2007-2013). yerleşme- şehirleşme özel ihtisas komisyonu raporu. (Yayın no: DPT: 2708- ÖIK: 661). Erişim adresi: 
https://www.sbb.gov.tr/wpcontent/uploads/2018/11/09_YerlesmeveSehirlesme.pdf

Evans, D.R. (1994). Enhancing quality of life in the population at large. Social Indicators Research. 33, 47-88. doi: https://doi.org/10.1007/BF01078958

Gehl, J. (2001). Life between buildings (5th Edition), Copenhagen: Danish Architectural Press.

Government of South Australia (2019). Tonsley urban design protocol. Erişim adresi: https:/tonsley.com.au/content/uploads/2020/07/2019.09-URBAN-DESIGNPROTOCOL_ISSUE-02.pdf

Onuncu Kalkınma Planı (2013, 6 Temmuz). Resmi gazete (Sayı 28699 Mükerrer). Erişim adresi: https://www.resmigazete.gov.tr/eskiler/2013/07/20130706M1-1.htm

Kostoff, S. (1999). The city assembled, London: Thames and Hudson

Lynch, K. (1981). Good city form. Cambridge: MIT Press.

Madanipour, A. (1996). Design of urban space. New York: Wiley.

Marans, R. (2017). Kentsel yaşam kalitesinin ölçülmesi. Mimarlık. 335. Erişim adresi: http://www.mimarlikdergisi.com/index.cfm?sayfa=mimarlik\&Dergi-

Sayi $=53 \& \operatorname{Rec} I D=1326$

Ministry for the Environment Manatü Mö Te Taiao. (2006). Urban design toolkit third edition. Erişim adresi: https:/www.mfe.govt.nz/sites/default/files/media/Towns\%20and\%20cities/urban-design-toolkit-third-edition.pdf

Project for Public Spaces. (2000). How to turn a place around: a handbook for creating successful public spaces. Newyork: PPS

Punter, J. (1999). Aesthetic control/design control in the United Kingdom. Urban Design International, 4(1\&2), 67-75.

Salihoğlu, T. ve Türkoğlu, H. (2019). Konut çevresi ve kentsel yaşam kalitesi. Megaron. 11(Ek 1), 203-217. doi: 10.5505/MEGARON.2018.06977

San Francisco Planning Department. (2018). San Francisco urban design guidelines. Erişim adresi: https://default.sfplanning.org/plans-and-programs/planning-for-thecity/Urban-Design-Guidelines/Urban_Design_Guidelines.pdf

Sennett, R. (2002). Kamusal insanın çöküşü. İstanbul: Ayrıntı Yayınları.

The City of Edinburgh Council. (2020). Edinburgh design guidance. Erişim adresi: https://www.edinburgh.gov.uk/downloads/file/27602/edinburgh-design-guidance-january-2020

The Government of the Hong Kong Special Administative Region. (2020). Hong kong planning standards and guidelines. Erişim adresi: https://www.pland.gov.hk/pland_en/tech_doc/hkpsg/full/pdf/ch11.pdf

United Nations. (2015). Transforming our world: the 2030 agenda for sustainable development. Erişim adresi: https://sdgs.un.org/2030agenda

United Nations. (2017). New urban agenda. Erişim adresi: http://habitat3.org/wp-content/uploads/New-Urban-Agenda-GA-Adopted-68th-Plenary-N1646655-E.pdf Urban Task Force. (1999). Towards an urban renaissance. London: Routledge. 
Uzgören, G., Erdönmez, M.Y. (2017). Kamusal açı alanlarda mekân kalitesi ve kentsel mekân aktiviteleri ilişkisi üzerine karşılaştırmalı bir inceleme. Megaron. 12(1), 4156. doi: https://doi.org/10.5505/megaron.2016.42650

Whyte, W.H. (1980). The social life of small urban spaces. New York: Project for Public Places.

World Health Organization QoL Group. (1995). The world health organization quality of life assessment (WHOQOL), Position Paper from the World Health Organization, Social Science And Medicine, 41(10), 1403-1409.

Yeang, L. D. (2000) Urban design compendium. London: English Partnerships.

Yener Metin, S. N. (2020). Kamusal mekân kalitesinin sağlanmasında kentsel tasarım araçlar-nın rolü. (Yüksek Lisans Tezi) https://acikerisim.uludag.edu.tr/bitstream/11452/11766/1/625463.pdf veri tabanından erişildi. 